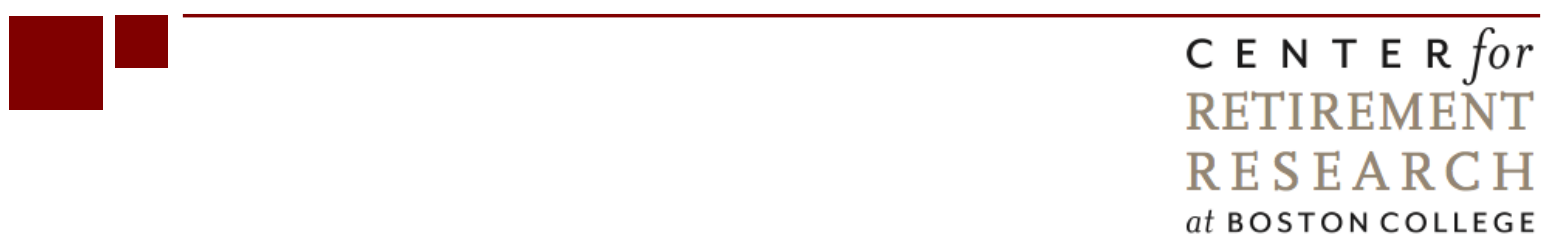

\title{
401(K) PARTICIPANT BEHAVIOR IN A VOLATILE ECONOMY
}

\author{
Barbara A. Butrica and Karen E. Smith
}

CRR WP 2012-24

Submitted: October 2012

Released: November 2012

\section{Center for Retirement Research at Boston College \\ Hovey House \\ 140 Commonwealth Avenue \\ Chestnut Hill, MA 02467}

Tel: 617-552-1762 Fax: 617-552-0191

http://crr.bc.edu

Barbara A. Butrica and Karen E. Smith are senior research associates in the Income and Benefits Policy Center at the Urban Institute. The research reported herein was pursuant to a grant from the U.S. Social Security Administration (SSA), funded as part of the Retirement Research Consortium (RRC). The findings and conclusions expressed are solely those of the authors and do not represent the views of SSA, any agency of the federal government, the RRC, the Urban Institute, or Boston College.

(C) 2012, Barbara A. Butrica and Karen E. Smith. All rights reserved. Short sections of text, not to exceed two paragraphs, may be quoted without explicit permission provided that full credit, including (C) notice, is given to the source. 


\title{
About the Center for Retirement Research
}

The Center for Retirement Research at Boston College, part of a consortium that includes parallel centers at the University of Michigan and the National Bureau of Economic Research, was established in 1998 through a grant from the Social Security Administration. The Center's mission is to produce first-class research and forge a strong link between the academic community and decision-makers in the public and private sectors around an issue of critical importance to the nation's future. To achieve this mission, the Center sponsors a wide variety of research projects, transmits new findings to a broad audience, trains new scholars, and broadens access to valuable data sources.

\author{
Center for Retirement Research at Boston College \\ Hovey House \\ 140 Commonwealth Avenue \\ Chestnut Hill, MA 02467 \\ phone: 617-552-1762 fax: 617-552-0191 \\ e-mail: crr@bc.edu \\ crr.bc.edu
}

Affiliated Institutions:

The Brookings Institution

Massachusetts Institute of Technology

Syracuse University

Urban Institute 


\begin{abstract}
The booms and busts of the late 1990s and 2000s have taken 401(k) plan participants on a rollercoaster ride. Using data from administrative tax records and household surveys, this paper examines how participants responded to these periods of economic expansions and contractions by documenting changes in $401(\mathrm{k})$ participation, contributions, and investment allocation from 1990 through 2010. Controlling for earnings, job changes, and other household factors, we show that 401(k) participation and contributions decline during recessions. The Great Recession could lower the 401(k) assets of the typical 30-year-old by as much as 9 percent at age 62 .
\end{abstract}




\section{Introduction}

Over the past 25 years, employment-based pensions have been shifting from traditional defined benefit (DB) plans in which employers bear most investment risks to defined contribution (DC) plans that place the investment responsibility on workers. Consequently, the number of households with retirement account assets has soared along with the number of households owning stocks inside those accounts — increasing from 12 percent in 1989 to 31 percent in 2008 (Investment Company Institute [ICI] and the Securities Industry and Financial Markets Association [SIFMA] 2008). About two-thirds of participants' assets in 401(k) plansthe most widely used type of employer-sponsored DC plan-were invested in equities in 2007 (ICI 2008).

As 401(k) plans were becoming increasingly popular, the economy experienced significant booms and busts. Between March 1991 and March 2001, the economy prospered for an unprecedented 10 years (NBER 2011). Then in 2000, the dot-com bubble burst and stock prices fell by double digits for three straight years. This triggered a relatively short recession in March 2001. The economy bounced back and expanded again for more than six years. Retirement account balances (defined contribution plans and IRAs) peaked at $\$ 8.7$ trillion in the third quarter of 2007 before plummeting \$2.7 trillion (31 percent) through the first quarter of 2009 as the stock market crashed (Butrica and Issa 2011). Although retirement account balances have now recovered much of their value, they would have been significantly higher had the market not crashed and instead continued on its pre-crash path. The 2008 stock market crash coincided with the Great Recession, the longest of any recession since World War II (NBER 2011), with the highest unemployment rates in nearly three decades and record-long unemployment spells.

While it's clear that the economy has taken investors on a rollercoaster ride of ups and downs during the past two decades, it is not clear how they have responded. Smith, Johnson, and Muller (2004) suggest that many plan participants adjust their contributions in response to life events, contrary to the popular perception that $401(\mathrm{k})$ contributions do not change much over time. Although the authors did not consider the effects of economic expansions and contractions, participants might increase their contributions and shift their investments into equities when the economy is expanding and the stock market booming, and decrease their contributions and shift away from equities when the economy is contracting and the market is 
falling. The state of the economy is also likely to influence $401(\mathrm{k})$ participation. Unemployed workers cannot participate, and financial pressures may lead some workers whose spouses lost their jobs to reduce $401(\mathrm{k})$ contributions even if they remain employed themselves. Indeed, Malmendier and Nagel (2007) find that individual experience with stock market returns and inflation influence investment behaviors with cohorts that experienced high inflation less willing to invest in long-term bonds and cohorts that experienced high stock market returns more willing to invest in equities.

This paper uses data from the Survey of Income and Program Participation linked to Social Security administrative data on earnings and contributions for 1990 through 2010. A major advantage of these data is that they are not subject to the same measurement error as workers' self-reported information because they come from actual tax records (Dushi, Iams, and Tamborini 2011). They also provide 21-year longitudinal measures of participation and contributions independent of workers' employers. We use these data to document changes in DC plan participation, contributions, and investment allocation between the late 1990s and late 2000s and examine how they correspond to changes in the economy. Do 401(k) participants stop contributing or reduce their contributions during economic downturns? Do participants react similarly to all economic downturns or do certain downturns, because of their severity, induce different or more dramatic behavioral responses? Do 401(k) participants respond more to busts than booms? Are retirement account portfolios more heavily invested in stocks when the economy is booming and less invested in stocks when the economy is failing? Although the analysis will not directly measure the impact of booms and busts on retirement account assets, the results will enable us to infer likely implications for account balances.

\section{Background}

Many Americans choose not to save for retirement and the reason may be related to the changing pension landscape. The percentage of workers covered by a traditional defined benefit pension plan that pays a lifetime annuity, often based on years of service and final salary, has been steadily declining over the past 25 years. Between 1989 and 2012, the proportion of private industry full-time workers participating in DB pension plans declined from 42 to 20 percent, while the share participating in defined contribution plans-investment accounts established and 
often subsidized by employers, but owned and controlled by employees - increased from 40 to 51 percent (Wiatrowski 2011; U.S. Bureau of Labor Statistics 2012).

Because DB pensions are tied to employers, workers do not have to think about retirement savings. They are automatically enrolled, contributions are automatically deducted, and benefits are automatically paid when workers retire. With DB pensions, employers bear the responsibility for ensuring that employees receive pension benefits. In contrast, DC retirement accounts are owned by employees. Workers have to actively decide to participate in the plan, how much to contribute, which investments to put their money in, and whether to take benefits as an annuity or lump sum payment at retirement. With DC retirement accounts, workers bear the responsibility for their own financial security. This requires that individuals make informed and forward-looking decisions at every step of the way. Moreover, in recent decades both the array of financial instruments and their complexity have increased-obligating investors to evaluate and understand many new and more sophisticated financial products. How well-equipped individuals are at making their savings decisions determines, at least in part, the amount of income in retirement they get to enjoy. But recent studies have revealed less than encouraging information about retirees' ability to adequately plan for retirement. While DC plans have the potential to provide retirees with substantial retirement wealth, a typical household approaching retirement had 401(k)/IRA balances of only \$42,000 in 2010 (Munnell 2012).

Moreover, differences in pension wealth across gender and racial groups are substantial (Butrica and Johnson 2010). While some of the differential is driven by factors beyond the individual's control, others such as participation, contribution level, and portfolio allocation are usually the result of the individual's decisions. If offered a plan, blacks and Hispanics are less likely to participate as compared to whites, they also tend to contribute a lower share of their earnings to the plan and are more likely to withdraw funds from their accounts or borrow from them. In addition, some evidence suggests that blacks, Hispanics, and women are often conservative investors and less willing to take on financial risk. However, it's not clear whether these conservative investment tendencies reflect innate preferences or merely blacks' and women's relatively limited wealth holdings (Bajtelsmit and Bernasek 2001; Schubert et al. 1999). Blacks and women are also less likely than others to invest their 401(k) funds in equities, which historically have had higher rates of return than other investment types (Ariel Investments and Hewitt Associates 2009). 
With all this in mind, it is not particularly surprising that participation rates among private wage and salary workers in 2012 who were offered an employer retirement plan were 89 percent in DB pensions but only 70 percent in DC plans (U.S. Bureau of Labor Statistics 2012). Even among full-time workers - whose participation rates are typically higher-participation rates were 91 percent in DB pensions but only 74 percent in DC plans (U.S. Bureau of Labor Statistics 2012). Do workers not participate because of inertia - which automatic enrollment can fix? Or do they not participate because they are scared off by the financial decisions and responsibilities that go hand-in-hand with DC plans?

If the policy goal is to help retirees be financially independent and minimize poverty at older ages, it is important to understand how individuals think about retirement planning and how they make their financial decision every step of the way. Are individuals well equipped to make their own sound financial decisions in an environment where the responsibility of retirement saving is increasingly shifting from employers to workers and financial products are becoming ever more complex? Assuming they are, how are their decisions influenced by lifecourse events or the economy?

A number of studies have examined the impact of stock market crashes and economic downturns on older workers' retirement decisions (Coile and Levine 2011; Coile and Levine 2006; Goda, Shoven, and Slavov 2010). Other studies have analyzed the impact of stock market and labor market conditions on retirement income and assets (Brady 2009; Burtless 2009; Coile and Levine 2010; Engen, Gale, and Uccello 2004; Gustman, Steinmeier, and Tabatabai 2009). Butrica, Smith, and Toder (2010) considered the impact of the 2008 stock market crash and alternative recovery scenarios on future retirement savings. The authors assumed that $401(\mathrm{k})$ participants would continue making the same total contributions to retirement accounts and would rebalance their portfolios to maintain the target allocation for their age. Their assumptions about how participants would behave in response to a stock market crash were necessary to isolate the effects of the stock market crash itself on retirement savings.

The current paper recognizes that retirement account assets depend not only on market performance, but also on individuals' behavior - whether individuals contribute, how much they contribute, and how they allocate their investment portfolio. It builds upon prior research by Smith, Johnson, and Muller (2004), which found that key lifecourse events, such as the birth of a child and the purchase of a home, influence contributions in defined contribution plans. It also 
builds upon research by Muller and Turner (2011), which used survey data and found that 401(k) participation is influenced by the performance of the stock market. Utkus and Young (2009), using Vanguard DC plan data, found that 16 percent of plan participants changed their asset allocation during 2008 (only slightly higher than the trading rates in the prior two years), but 4 percent of assets were shifted from equities to fixed income investments (the largest net shift in over 10 years).

However, the recent rise in automatic enrollment and diversified investment options including target date funds may dampen expected changes in worker contribution behavior surrounding the recessions and market fluctuations (BLS 2011b). Among workers participating in their employer's DC plans, the share with plans that included automatic enrollment increased from 5 percent in 2003 to 21 percent in 2010 (Costo 2006; Bureau of Labor Statistics 2011c). Many of these workers will be assigned a default contribution rate and default investment fund because they did not make their own elections. Given these trends, it is not surprising that a 2012 Morningstar industry survey found a fivefold increase in target date fund assets in the last six years, increasing from $\$ 71$ billion in 2005 to $\$ 378$ billion in 2011 (Charlson and Lutton 2012).

This analysis extends previous studies by using more recent data and focusing on the extent to which workers adjust their participation, contributions, and asset portfolios during economic booms and busts.

\section{Methodology}

We examine contributions to employer-sponsored retirement plans over time and how they interact with key lifecourse events for a large sample of workers. The data come from the 1996, 2001, 2004, and 2008 panels of the Survey of Income and Program Participation (SIPP) pooled together and linked to administrative data from the Social Security Administration's (SSA) Detailed Earnings Record (DER) and Summary Earnings Record (SER).

The SIPP provides basic demographic data, including age, race, gender, marital status, and education, as well as information about employment status, income, and earnings. Special topical modules provide additional information on marital histories, fertility histories, employment histories, disability, asset holdings, and employer-sponsored pension participation. In particular, the survey asked respondents with work limitations about when their health problems started, and asked homeowners about when they purchased their homes. Thus, the data 
allow us to identify the timing of key lifecourse events, including marriages, divorces, widowhood, the birth of a child, the onset of health problems that limit the ability to work, and the purchase of a home. Because the survey interviewed all adult members of the household, it also provides information about key transitions in the spouse's life.

The DER contains information collected from the Internal Revenue Service's Form W-2, which employers must file to report salaries and benefits they pay to their employees, as well as self-employment income from Schedule SE (Olsen and Hudson 2009). The DER provides annual information on total earnings, earnings covered by Social Security and Medicare, taxable earnings from 1978 to 2010, and worker contributions to employer-sponsored retirement accounts from 1990 to 2010. ${ }^{1}$ The DER file also includes employer identification codes that enable users to calculate job tenure and identify respondents who change jobs over time.

The SIPP topical modules provide contemporaneous information, as well as retrospective data for marriage histories, fertility histories, and disability histories. The DER match provides both retrospective and prospective earnings and DC contributions relative to the SIPP interview period. Our analyses use two samples: one that includes both retrospective and prospective DER earnings and contributions, and one that includes only retrospective DER data. The former sample allows us to examine DC participation and contribution patterns over the 21-year period from 1990 to 2010 and relate them to non-changing demographic characteristics observed on the SIPP (for example, sex, birth year, race, and educational attainment). The latter sample allows us to examine DC participation and contribution patterns from 1990 to the SIPP interview year and relate them to characteristics known from the SIPP retrospective data (for example, marital status, number of dependents, disability and health status, homeownership, and pension characteristics).

We restrict the sample to wage and salary workers ages 20 to 69 who report positive earnings in the given year. ${ }^{2}$ We exclude workers younger than 20 because many employers do

\footnotetext{
${ }^{1}$ Administrative match rates vary by SIPP panel. The match rate was 79 percent for the 1996 SIPP, 47 percent for the 2001 SIPP, 73 percent for the 2004 SIPP, and 80 percent for the 2008 SIPP. Czajka, Mabli, and Cody (2008) examined attrition and match bias in the SIPP data. They found that the nonmatched cases in the 2001 panel appeared fairly similar to matched cases on a number of important dimensions, and that nonmatch bias did not appear to differ greatly from that present for the 1996 SIPP.

${ }^{2}$ The DER provides annual wage reports for all employers in each calendar year. For workers with multiple employers, we do not know if the jobs were held sequentially or concurrently. We pool earnings from all jobs in each calendar year.
} 
not allow them to participate in retirement plans, and we exclude workers older than 69 because people must begin withdrawing funds from defined contribution plans at age $701 \frac{1}{2}$. Our sample includes 902,344 person-year observations between 1990 and 2010 for over 168,000 individuals. We express all dollar amounts in constant 2011 dollars (indexed to changes in the Consumer Price Index).

We define wage and salary workers as individuals with positive earnings from any job in a calendar year and with at least half of their total annual earnings from wage and salary employment. ${ }^{3}$ Workers are offered DC plans if: 1) they report on the SIPP pension topical module that their employer offered a DC plan and that they were eligible to participate in the plan; or 2) they made a DC contribution in any year while on the pension job up to and including the SIPP pension topical module year. ${ }^{4}$ Workers participate in DC plans if they make a contribution to any DC plan, excluding employer-only contributions, personal IRA contributions, or self-employed Keogh contributions. We sum all worker contributions (as reported in Box 12 of workers' W-2 forms) from all jobs in a calendar year to create our measure of total annual contributions, and we divide this amount by total annual earnings to create our measure of contribution rates. ${ }^{5}$

We begin our analyses by showing how DC offer rates have changed over time. We then show participation rates, contribution levels, and contribution rates by year, age, and earnings level. We then estimate logit models of the participation decision and linear regression models of the level of contributions for workers contributing to their retirement plans. Predictors in the models include age and its square (to capture nonlinear effects of age), age splines with kinks at age $30,40,50$, and 60, marital status, log of own earnings, number of work years since age 20, unemployment (measured as a full calendar year with no earnings), the number of children under age 18 , the presence of a work limitation, the presence of a working spouse, and indicators

\footnotetext{
${ }^{3}$ The DER separately reports self-employment and wage and salary earnings.

${ }^{4}$ For 1996 SIPP respondents, we look at DC contributions for all years on the pension job (identified by the employer identification number) from 1990 to 1998 (the year of the pension topical module). For 2001 SIPP respondents, we look at DC contributions on the pension job through 2003. For 2004 SIPP respondents, we look at DC contributions on the pension job through 2006. For 2008 SIPP respondents, we look at DC contributions on the pension job through 2009.

${ }^{5}$ Total earnings are the sum of wage and salary earnings, including the deferred earnings, and self-employment earnings.
} 
(during the current year) of the onset of work limitations, the purchase of a home, the birth of a child, the death of a spouse, the dissolution of a marriage through divorce, and a job change. ${ }^{6} \mathrm{We}$ also experiment with lagging these indicators, to explore whether the impact on retirement contributions persists a few years after the event. We also include SIPP panel dummies and year dummies to capture changes in 401(k) behavior over time. We are particularly interested in the sign and magnitude of the year dummies and their relationship to macro-economic conditions including the unemployment rate and gross domestic product (GDP).

We also examine retirement asset allocation using self-reported data from the SIPP pension and asset topical modules and measure how asset allocation has changed over time. ${ }^{7}$ This data is limited to the SIPP interview years. The pension module collects information about the flows into retirement accounts among workers contributing to DC pensions. The asset module collects information about the stock of retirement account assets among individuals with retirement accounts. Unfortunately, neither the pension nor the asset topical module provides information on the share of investments by investment type. Instead, they provide only indicators of the type of investments owned. We exploit these indicators to examine people's willingness to invest in equities and whether this has changed over time given the dual 2001 and 2008 stock market crashes.

For workers contributing to their DC pensions, the SIPP asks if workers invest assets in company stocks, stock funds, corporate bonds or bond funds, long term interest bearing securities, diversified stock and bond funds, government securities, money market funds, or other investments. The 2008 SIPP panel added "evenly split between types" to their list of DC investment types. These workers are then asked "of the types of investments just mentioned, which type is where the largest share of current contributions are being invested?" While we know the majority investment type, we do not know the specific share of each investment type.

\footnotetext{
${ }^{6} \mathrm{~A}$ job change is a worker working for an employer in year $t$ who was not working for that employer in year $t-1$ identified by the employer identification numbers on the DER. Number of work years includes all years with positive earnings from the DER or SER starting at age 20. The SER includes annual Social Security covered earnings from 1951 to 2010 .

${ }^{7}$ The 1996 SIPP panel asks the pension module in wave 7 (1998) and wealth module in waves 3, 6, 9, and 12. The 2001 SIPP panel asks the pension module in wave 7 (2003) and wealth modules in wave 3, 6, and 9. The 2004 SIPP panel asks the pension module in wave 7 (2006) and the wealth modules in waves 3, and 6. The 2008 SIPP panel asks the pension module in wave 3 (2009) and the wealth modules in waves 4 and 7 . We examine the wealth module asked nearest to the pension module (waves 6 and 7 for the 1996, 2001, and 2004 panels and waves 3 and 4 for the 2008 panel).
} 
For individuals reporting retirement account assets in IRA, Keoghs, and DC plans (401(k), 403(b), or thrift plans), the SIPP asks how these accounts are allocated. Respondents can choose certificate of deposit or other saving certificates, money market funds, U.S. government securities, municipal or corporate bonds, stock or mutual fund shares, or other assets. The SIPP collects up to four investment types for IRA, Keogh, and DC balances (12 possible reports). While we can measure the share of account holders with retirement account balances invested in different types of investments, we do not know the amount invested in each type. Unlike the pension topical module that asks about the majority investment type, this is not asked about account balances. This limited information, however, does allow us to measure workers willingness to invest in stocks and other asset types and how this has changed over time.

\section{Results}

DC Offer Rates. The share of wage and salary workers offered DC plans has increased over time, rising from 54 percent in 1998 to 63 percent in 2009 (Figure 1). This trend reflects the increase in employers offering DC pensions - either replacing or in addition to their DB pensions, as well as the increase in finance and service jobs that typically offer DC plans and decline in manufacturing jobs that typically offered DB pensions. Although DC offer rates increased for all age groups, prime age workers, those ages 30 to 59, are more likely to work in jobs that offer DC pensions than are younger or older workers.

Participation. Among wage and salary workers ages 20 to 69, the share contributing to employer-sponsored retirement accounts increased sharply between 1990 and 2001 as employers increasingly offered workers DC plans (rising from 22.5 to 40.2 percent) (Figure 2). Participation then dipped slightly between 2001 and 2003 (falling from 40.2 to 39.1 percent) with the 2001 recession, dot.com stock market crash, and high unemployment period from 2002 to $2004 .^{8}$ After 2003, participation rates increased again, but much more gradually to peak at 42.7 percent in 2008. Coinciding with the Great Recession, participation rates fell in 2009 and 2010 to 41.1 percent

\footnotetext{
${ }^{8}$ The national unemployment rate increased from 4 percent in January 2000 to 6.3 percent in June 2003 . It then fell to 4.4 percent in May 2007 before rising to 10 percent in October 2009. Unemployment remained above 9 percent for all of 2010 (BLS 2011a).
} 
As DC plans became more common, participation rates at all ages increased between 1990 and 2001 (Figure 3). Since 2001, participation rates leveled off for workers under age 50 but continued to rise for workers over age 50. Note, however, that participation rates have distinct recession dips between 2001 and 2003 and between 2008 and 2010. The recession dips are bigger for younger workers than for older workers, but participation rates declined for all workers under age 60 during both recessions. Although participation rates for each cohort are higher at every age than for the preceding cohort at the same age; participation rates at ages 40 to 49 appear to have plateaued for cohorts born after 1946 (Figure 4). Furthermore, participation rates are lower for workers after age 59. Because these workers had DC offers and participated at younger ages, their lower participation at older ages is not solely due to lack of offers.

Much of the observed changes in historic DC participation rates reflect changes in employer offer rates. Only workers offered a DC plan can participate and offer rates have increased over time as employers increasingly offer these types of plans. Unfortunately, we do not know historic offer rates from the administrative data. The SIPP pension topical module asks workers if their employer offers a DC-type pension plan, but this is only known at the SIPP interview. About 40 percent of wage and salary workers in 2006 did not participate in a DC plan because their employer did not offer a plan (Figure 5). Around a third of workers ages 30 to 59 did not participate because their employer did not offer a plan in 2006, compared with 61 percent of workers ages 20 to 29 and 50 percent of workers ages 65 to 69 .

Participation rates among workers offered a DC plan are higher than participation rates among all workers. About 69 percent of workers offered a DC plan in 2006 made contributions to their plan (Figure 6). Participation rates rise among those offered a plan with age until age 59 and decline at older ages. Younger and older workers are both less likely to be offered a DC plan and less likely to participate when they are offered a plan compared with workers in their $50 \mathrm{~s}$.

Conditional on having a DC plan offer, we still see a significant drop in DC participation between 2006 (based on the 2004 SIPP panel) and 2009 (based on the 2008 SIPP panel) in response to the Great Recession. Among all workers offered a DC plan, participation fell from 69.1 percent in 2006 to 66.3 percent in 2009. While participation rates are highest among 40-49 year-olds and 50-59 year-olds, these groups also experienced the largest drops in participation between 2006 and 2009. 
Contribution Levels and Rates. Changes in the median DC contribution amounts mirrored changes in the GDP between 1990 and 2010 - particularly starting in 2002 (Figure 7). For example, amid booming economies median DC contributions increased 19.1 percent between 1992 and 1999 (about 2.5 percent per year) and 3.7 percent between 2002 and 2004 (about 1.8 percent per year) (Table 1). They declined 4.6 percent between 2004 and 2007 as the booming housing market began to reverse and another 4.9 percent between 2007 and 2009 (-2.5 percent per year) with the stock market crash and Great Recession. They remained relatively unchanged between 2009 and 2010.

Workers ages 50 to 64 were the hardest hit by the recent economic downturn (Figure 8, Table 1, and Table 2). Between 2007 and 2009, median contributions declined 9.3 percent from $\$ 3,530$ to $\$ 3,203$ for those ages 50 to 59 and 8.7 percent from $\$ 3,529$ to $\$ 3,224$ for those ages 60 to 64 . Contributions of workers ages 65 to 69 declined the least over this time period —only 3.6 percent from $\$ 2,983$ in 2007 to $\$ 2,877$ in 2009 . In 2010, contributions rebounded for workers ages 50 to 64 , but continued to fall for workers ages 20 to 29 , those ages 40 to 49 , and those ages 65 to 69 (Figure 9). Still, contribution levels in 2010 were lower than they were in 2007-for all age groups.

The lowest and highest earners experienced the largest decline in contributions levels as a result of the recession (Figure 10, Table 3, and Table 4). Compared with their DC contributions in 2007, workers making under $\$ 10,000$ contributed 11.4 percent less in 2009 and 12.1 percent less in 2010. Those earning $\$ 10,000$ to $\$ 15,000$ contributed 5.0 percent less in 2009, but 1.9 percent more in 2010. At the other end of the earnings distribution, workers making $\$ 80,000$ to $\$ 100,000$ contributed 5.8 percent less in 2009 and 4.8 percent less in 2010. And workers making more than $\$ 100,000$ contributed 7.2 percent less in 2009 and 4.9 percent less in 2010. Since median contribution amounts are well below the statutory maximum contribution limits, reductions in contribution amounts are not due to changes in contribution limits, which increased over this period.

Contributions can increase even if workers don't change their contribution rates. All else equal, contributions will increase if earnings increase. However, we also find that contribution rates (contribution amount divided by total earnings) declined with the Great Recession (Figure 11 and Table 5). For the typical DC participant, contribution rates declined 2.2 percent between 2007 and 2009, from 5.1 to 5.0 percent. The largest changes occurred among the oldest workers. 
Between 2007 and 2009, median contribution rates declined 7.8 percent for workers ages 60 to 64 and 7.1 percent for those ages 65 to 69 . In contrast, they declined only 2.1 percent for workers ages 20 to 29. Contribution rates declined further in 2010 for workers ages 20 to 29 and those ages 65 to 69 (Figure 12). By 2010, their median contribution rates were 4.3 and 8.4 percent lower, respectively, than in 2007. In contrast, contribution rates increased slightly for workers ages 50 to 59 and those ages 60 to 64. Still, their median contribution rates in 2010 were 2.8 and 5.1 percent lower, respectively, than in 2007.

Among participants, median contribution rates for the lowest earners declined 15.8 percent between 2007 and 2009 from 4.0 to 3.4 percent (Figure 13 and Table 6). They declined 6.9 percent for workers earning $\$ 40,000$ to $\$ 50,000$ from 4.9 to 4.6 percent. Median contribution rates also declined 3.7 percent from 6.3 to 6.0 percent for workers making $\$ 80,000$ to $\$ 100,000$.

Multivariate Analysis of Participation. Table 7 reports logistic regression coefficients of DC participation among workers from 1991 to 2010. Models 1 and 2 vary only in the age specification: model 1 includes age and age squared and model 2 includes age spines. Both models show that workers' probability of participating increased with earnings, more work years, and age (but at a decreasing rate). Workers who changed jobs or returned to work after a spell of unemployment were less likely to participate in a DC plan surrounding their job change. This may reflect waiting periods for new workers or failure to initially enroll in offered plans with new employers. Our key variables of interest here are the year dummies. The probability that a worker contributed to a DC plan increased every year between 1991 and 2001, but then declined between 2001 and 2003 as the recession progressed and unemployment rates increased. Participation probabilities increased again between 2004 and 2008 and then declined after 2008 as the recession progressed and unemployment rates increased. The impact of the 2001 and 2008 recessions on participation probabilities continued past the official end of both recessions.

We see similar declines in DC participation associated with the 2001 and 2008 recessions using the retrospective sample that is limited to wage and salary workers offered a DC plan (Table 8). We expand the set of explanatory variables to include characteristics known from the SIPP retrospective data including spouses' earnings and DC contributions, health, and pension characteristics. We also limit the sample to include only years the worker was with the employer that offered the DC plan in the SIPP pension topical module. The models in Table 8 control for many of the same variables as in Smith, Johnson, and Muller (2004), but also include year 
dummies. ${ }^{9}$ Models 1 and 2 vary only in the age specification: model 1 includes age and age squared and model 2 includes age splines. Again, we see a decline in participation following the 2001 and 2008 recessions. Figure 14 graphically compares the unadjusted logistic parameter estimates for the year dummies using both the sample of all workers and the sample of workers offered a plan (omitted year is 1991). The coefficients in the model of all workers represent a 1.9 percentage point reduction between 2001 and 2003 and a 1.7 percentage point reduction between 2008 and 2010 due to the recessions. ${ }^{10}$

Multivariate Analysis of Contribution Amount. Table 9 reports the results from our OLS regression of 401(k) retirement contributions for participating workers. Holding other factors constant, contributions increased from 1995 through 1998, declined until 2000, and then increased until 2006 where they leveled off until 2007. After 2007, contributions declined until 2009 and leveled off until 2010. Models 1 and 2 are identical except for the age specification, and both models find nearly identical contribution patterns by year.

Table 10 reports the results from a similar regression based on the retrospective sample (1990 to SIPP interview period only). This sample allows us to add additional explanatory variables available from the SIPP data but not known after the SIPP panel. This model controls for many of the same variables as in Smith, Johnson, and Muller (2004) and also includes year dummies. Despite these differences, many of the relationships shown in this table are similar to those in the original study. Although the coefficients on the year dummies are lower in this model than in the model reported in Table 9, the pattern of contributions over time is identical (shown graphically in Figure 15).

Unfortunately, our data do not include information about automatic enrollment. They also do not include information about changes in employer contributions in years other than the SIPP pension topical module year. Participation and contribution behaviors are likely affected by these and other factors we cannot control for. Despite these limitations, our results strongly suggest that economic forces, beyond just their effects on earnings and employment, influence workers' retirement saving behavior.

\footnotetext{
${ }^{9}$ Because the models include lagged terms, we exclude 1990 from the sample and omit 1991 from the models.

${ }^{10}$ For workers offered a DC plan, the recessions lowered their probability of participating 1.2 percentage points between 2001 and 2003 and 1.7 percentage points between 2008 and 2009 .
} 
Workers, concerned about a future job loss, may stop contributing to their DC plan to not tie up saving in DC accounts that face tax penalties for withdrawals before age $59 \frac{1}{2}$. To test this hypothesis, we included forward-looking unemployment dummies in the participation and contribution functions for those under age 59 who face penalties and those over age 59 who do not face penalties. Results (not shown) find no significant effect of future unemployment on younger worker's participation, but a positive and significant effect for older workers where unemployment (no earnings in the next calendar year) include both retirement and full-year unemployment. Future unemployment increased contributions modestly for both younger and older participants. In all cases, including forward-looking indicators did not change our measured recession effects, nor did adding controls for whether the DC plan was a 401(k), 403(b), or other type DC plan. ${ }^{11}$

\section{Investments}

This section first examines how wage and salary workers allocate their DC contributions - that is the flows into retirement accounts. It then examines how individuals with retirement accounts have invested those assets - that is the stock of assets. This analysis is based on self-reported SIPP data and is limited to the pension and asset topical module years.

The percentage of workers investing their DC contributions in bonds increased dramatically with the recession from 38.0 percent in 2006 to 54.8 percent in 2009 (Figure 16). Similarly, those investing in mixed stocks and bonds increased from 36.8 to 52.8 percent. ${ }^{12}$

Between 1998 and 2009, workers shifted their primary 401(k) investment type away from money markets accounts to diversified stock and bond investments (Figure 17). Participant's primary DC investment type shifted away from stock funds with both the 2001-2003 and 20082009 stock market crashes. Despite the volatile stock market fluctuations over this period, DC participants have not abandoned equities but have shifted assets into more diversified investments. In 2006, 34.1 percent of DC participants invested primarily in employer stock or stock funds and 22.7 percent invested primarily in diversified stock bonds. In 2009, only 24.1 percent primarily invested their DC contributions in employer stock or stock funds, but 38.0

\footnotetext{
${ }^{11}$ Beginning in 2004, the DER reports the DC plan type for DC contributions.

${ }^{12}$ Workers are invested in stocks if they report contributions to company stocks, stock funds, or diversified stock and bond funds. They are invested in bonds if they report contributions to bond funds or diversified stock and bond funds, and they are invested in fixed income accounts if the invest in long-term interest securities, government securities, money market, or other investments.
} 
percent invested primarily in diversified stock bonds. The share investing their DC contributions primarily in money market accounts declined from 23.8 percent in 1998 to only 12.0 percent in 2009.

Next we use multivariate analysis to consider the probability that workers invest their DC contributions in stocks and how that has changed over time (Table 11). Workers whose employers contribute to the plan are 55 percent more likely to invest in stocks than those whose employers do not contribute. In addition, having a plan that permits borrowing increases the likelihood of investing in stocks by 56 percent. However, we find no evidence that the likelihood of investing 401(k) contributions in stocks has changed between 2001, 2003, 2006, and 2009.

Among all adults with retirement accounts, the share with stocks or mutual funds declined between 2006 and 2009 from 83.1 to 75.4 percent, and the share with certificates of deposit, money market accounts, or government securities increased from 31.3 to 40.6 percent (Figure 18).

Table 12 reports the results from a multivariate analysis that considers the probability that retirement account owners invest their balances in stocks and how that has changed over time. In addition to those variables reported in Table 11 to be correlated with investing in stocks, homeownership, earnings, and work experience are all correlated all increase the likelihood that retirement account balances are invested in stocks. We also find that the probability of holding retirement account assets in stocks has changed over time. Compared with 1998, retirement account owners were 58.7 percent more likely to invest in stocks in 2003 and 63.7 percent more likely to invest in stocks 2006 . However, they were only 52.9 percent more likely to invest in stocks in 2009 (a 10.8 percentage point decline relative to 2006).

Some of the changes in investment allocations over time reflect employers' adoption of target date funds as their default investment type, but the fluctuation in and out of stock funds around the stock market crashes suggests that some workers do adjust their investment portfolio in response to how the market performs. However, the observed behavior is contrary to wise investment advice. Instead of buying equities when the price is low and selling equities when the price is high, some investors appear to do the opposite. The correlation between the DC investment behavior reported in the SIPP pension topical module and the retirement account allocation reported in the SIPP wealth topical module is poor. 


\section{Discussion}

If the typical worker had done nothing in 2007 and kept his contributions in 2008 and 2009 at the 2007 level, instead of reducing them, his account balances would have been at least $\$ 210$ higher at the end of 2009 (Table 13). If he had increased his contributions just 1 percent each year after 2007, his account balances would have been at least \$289 higher at the end of 2009. The long-run impacts are even greater, especially when compounded over many years.

The typical 30-year-old worker reduced his contributions by $\$ 138$ or 6 percent between 2007 and 2010 (see Figure 9). His retirement account balance at age 62 is projected to be just under $\$ 134,000$ (Table 14). (This assumes contributions begin increasing 1 percent per year after 2010 and that accumulated balances earn a 3 percent annual rate of return). If instead of reducing his contributions starting in 2007, he increased them just 1 percent each year, his account balance at age 62 would be $\$ 145,572$ - a difference of $\$ 11,907$ or 8.9 percent. The further individuals were from retirement when the recession occurred and the higher their contributions before the recession, the larger the potential negative impact on their retirement savings. Of course, workers can recoup some or all of their investment losses by increasing their future contributions. For example, our hypothetical worker could recoup all of his losses from the recession by increasing his baseline contribution $\$ 232$ plus making a one-time catch-up contribution of $\$ 520$ all in 2011 , and then continuing future contributions at the higher level under the alternative scenario. The regression results in Table 8 show that participation is lower immediately following a spell of unemployment, suggesting it is difficult to get back on track after losing a job. But for workers who do contribute after an unemployment spell (see Table $10)$, they tend to contribute higher amounts on average in an attempt to catch up. For those who don't catch up, the recession will amount to a real loss in retirement savings.

\section{Conclusions}

With the erosion of DB pensions and the growth in DC plans, sound retirement planning increasingly depends on the commitment of individuals to invest in retirement accounts throughout their work lives. A better understanding of the factors influencing workers' 401(k) behavior could help policymakers design policies that encourage higher participation and contribution levels throughout workers' careers, thus enhancing private retirement savings so that retirees may rely less on Social Security benefits. 
We find that the Great Recession, more than each of the previous two recessions, had a large negative impact on DC participants' behavior. Participation dropped off slightly, while contribution amounts and contribution rates declined dramatically - even after controlling for other factors. The decline in worker participation after the 2001 and 2008 recessions occurred despite the increased adoption of automatic enrollment. The decline in participation is especially sharp for younger workers who were more likely to be new employees and automatically enrolled in their employers' retirement plans. This suggests that economic forces outweigh inertia in participation decisions.

Furthermore, those with retirement accounts were much more likely to invest in bonds after the recession than they were before the recession. The increased prevalence of target date funds can help unsophisticated investors make better investment choices, but this only works if the default investments are good choices. While automatic enrollment and target date funds were established largely to help fight inertia, there is rising concern that defaults may lower retirement savings (Tergesen 2011).

Although the typical worker reduced his contributions only $\$ 130$ as a result of the Great Recession, this represented a decline of 4.9 percent. This is especially troubling when one considers that the median contribution amount before the recent recession began was only about $\$ 2,600$ - far less than the 2007 legislated contribution limits of $\$ 15,500$ for workers under age 50 and $\$ 20,500$ for those ages 50 and older. Workers were already contributing to their retirement savings far less than permitted, and now they are contributing even less.

Finally, our results suggest that workers' participation and contribution decisions are not always made simultaneously, at least with regard to their response to recessions. As the economy falters, workers first lower their contribution amounts and later change their decision to participate. Lower contributions precede recessions, while lower participation follows recessions. 


\section{References}

Ariel Investments and Hewitt Associates. 2009. “401(k) Plans in Living Color: A Study of 401(k) Plans Across Racial and Ethnic Groups.” Chicago, IL: Ariel Investments.

Bajtelsmit, Vickie L., and Alexandra Bernasek. 2001. "Risk Preferences and the Investment Decisions of Older Americans.” Washington, DC: AARP.

Brady, Peter. 2009. "What Does the Market Crash Mean for the Ability of 401(k) Plans to Provide Retirement Income? National Tax Journal, 62(3): 455-476.

Bureau of Labor Statistics. 2012. "Employer Costs for Employee Compensation - June 2012". http://www.bls.gov/news.release/ecec.nr0.htm, accessed September 2012.

Bureau of Labor Statistics. 2011a. "Labor Force Statistics from the Current Population Survey." Washington, DC: U.S. Department of Labor. http://data.bls.gov/timeseries/LNS14000000.

Bureau of Labor Statistics. 2011b. "Defined-Contribution Investment Choices: Employees Given Range of Investment Options in 401(k) Plans." Washington, DC: U.S. Department of Labor. Program Perspectives. Volume 3. Issue 5. http://www.bls.gov/opub/perspectives/program_perspectives_vol3 issue5.pdf.

Bureau of Labor Statistics. 2011c. "Table 23. Savings and Thrift Plans: Automatic Enrollment, Private Industry Workers, National Compensation Survey, 2010.” http://www.bls.gov/ncs/ebs/detailedprovisions/2010/ownership/private/table23a.pdf.

Burtless, Gary. 2009. "Financial Market Turbulence and Social Security Reform.” In M. A. Orenstein (Ed.), Pensions, Social Security, and the Privatization of Risk (pp. 72-85). New York, NY: Columbia University Press.

Butrica, Barbara A., and Philip Issa. 2011. "Retirement Account Balances.” Fact Sheet on Retirement Policy. Washington, DC: Urban Institute.

Butrica, Barbara A. and Richard W. Johnson. 2010. "Racial, Ethnic, and Gender Differentials in Employer-Sponsored Pensions." Testimony to the ERISA Advisory Council, U.S. Department of Labor, June 30, 2010.

Butrica, Barbara A., Karen E. Smith, and Eric J. Toder. 2010. "What the 2008 Stock Market Crash Means for Retirement Security.” Journal of Aging \& Social Policy. 22(4): 339-359.

Charlson, Josh and Laura Lutton. 2012. "Target-Date Series Research Paper: 2012 Industry Survey.” Morningstar Research Fund.

Coile, Courtney C. and Phillip B. Levine. 2006. "Bulls, Bears, and Retirement Behavior." Industrial and Labor Relations Review. 59(3): 408-429. 
_ 2010. "Recessions, Reeling Markets, and Retiree Well-Being." NBER Working Paper No. 16066. Cambridge, MA: National Bureau of Economic Research.

— 2011. "The Market Crash and Mass Layoffs: How the Current Economic Crisis May Affect Retirement." The B.E. Journal of Economic Analysis \& Policy. 11(1): Article 22.

Costo, Stephanie. 2006. "Trends in Retirement Plan Coverage over the Last Decade.” Monthly Labor Review. February: 58-64.

Czajka, John L., James Mabli, and Scott Cody. 2008. "Sample Loss and Survey Bias in Estimates of Social Security Beneficiaries: A Tale of Two Surveys." Report to SSA. Washington, D.C.: Mathematica Policy Research, Inc.

Dushi, Irena, Howard M. Iams, and Christopher R. Tamborini. 2011. "Defined Contribution Pension Participation and Contributions by Earnings Levels Using Administrative Data." Social Security Bulletin 71(2): 67-76.

Engen, Eric M., William G. Gale, and Cori E. Uccello. 2004. "Effects of Stock Market Fluctuations on the Adequacy of Retirement Wealth Accumulation." Working Paper No. 2004-16. Chestnut Hill, MA: Center for Retirement Research at Boston College.

Goda, Gopi Shah, John B. Shoven, and Sita Nataraj Slavov. 2010. "Does Stock Market Performance Influence Retirement Expectations?” NBER Working Paper No. 16211. Cambridge, MA: National Bureau of Economic Research.

Gustman, Alan L., Thomas L. Steinmeier, and Nahid Tabatabai. 2009. "What the Stock Market Decline Means for the Financial Security and Retirement Choices of the Near-Retirement Population." NBER Working Paper No. 15435. Cambridge, MA: National Bureau of Economic Research.

Investment Company Institute (ICI). 2008. “401(k) Plan Asset Allocation, Account Balances, and Loan Activity in 2007.” Research Perspective No. 14(3). Washington, DC: ICI.

Investment Company Institute (ICI) \& the Securities Industry and Financial Markets Association (SIFMA). 2008. "Equity and Bond Ownership in America." Washington, DC: ICI \& SIFMA.

Malmendier, Ulrike and Stefan Nagel. 2007. "Depression Babies: Do Macroeconomic Experiences Affect Risk-Taking?" Cambridge, MA: National Bureau of Economic Research.

Muller, Leslie A, and John A. Turner. 2011. "The Persistence of Employee 401(k) Contributions Over a Major Stock Market Cycle: Evidence on the Limited Power of Inertia on Savings Behavior." Upjohn Institute Working Paper 11-174. Kalamazoo, MI: W.E. Upjohn Institute for Employment Research. 
Munnell, Alicia H. 2012. "401(k) Plans in 2010: An Update from the SCF." Issue in Brief No. 12-13. Chestnut Hill, MA: Center for Retirement Research at Boston College.

National Bureau of Economic Research. 2011. "US Business Cycle Expansions and Contractions." http://www.nber.org/cycles/cyclesmain.html.

Olsen, Anya, and Russell Hudson. 2009. "Social Security Administration's Master Earnings File: Background Information." Social Security Bulletin 69(3): 29-45.

Schubert, Renate, Martin Brown, Matthias Gysler, and Hans Wolfgang Brachinger. 1999. "Financial Decision-Making: Are Women Really More Risk-Averse?" American Economic Review 89(2): 381-85.

Smith, Karen E, Richard W. Johnson, and Leslie Muller. 2004. "Deferring Income in EmployerSponsored Retirement Plans: The Dynamics of Participant Contributions." National Tax Journal. 57(3): 639-670.

Utkus, Stephen, and Jean Young. 2009. "Inertia and Retirement Savings: Participant Behavior in 2008." Valley Forge, PA: Vanguard Center for Retirement Research.

Tergesen, Anne. 2011. “401(k) Law Suppresses Saving for Retirement.” Wall Street Journal. July 7, 2011.

Wiatrowski, William J. 2011. "Changing Landscape of Employer-Based Retirement Benefits." Bureau of Labor Statistics. Available: http://www.bls.gov/opub/cwc/print/cm20110927ar01p1.htm. 
Figure 1. DC Offer Rate among Wage and Salary Workers by Age and Year

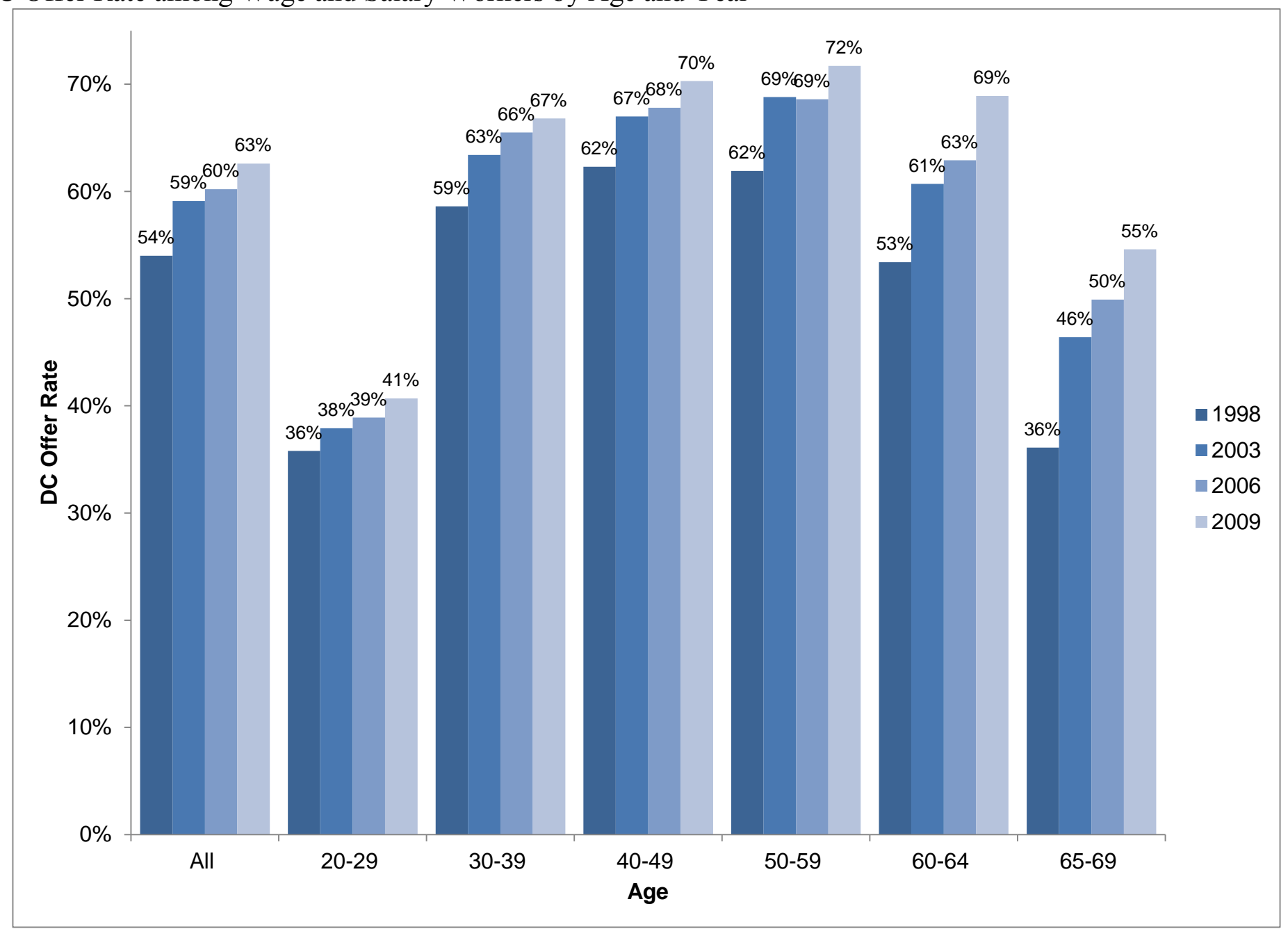

Source: Authors' tabulations of the 1996, 2001, 2004, 2008 SIPP pension topical modules matched to the Social Security Administration's Detailed Earnings Record (DER). 
Figure 2. Participation Rate among Wage and Salary Workers Ages 20 to 69, by Year

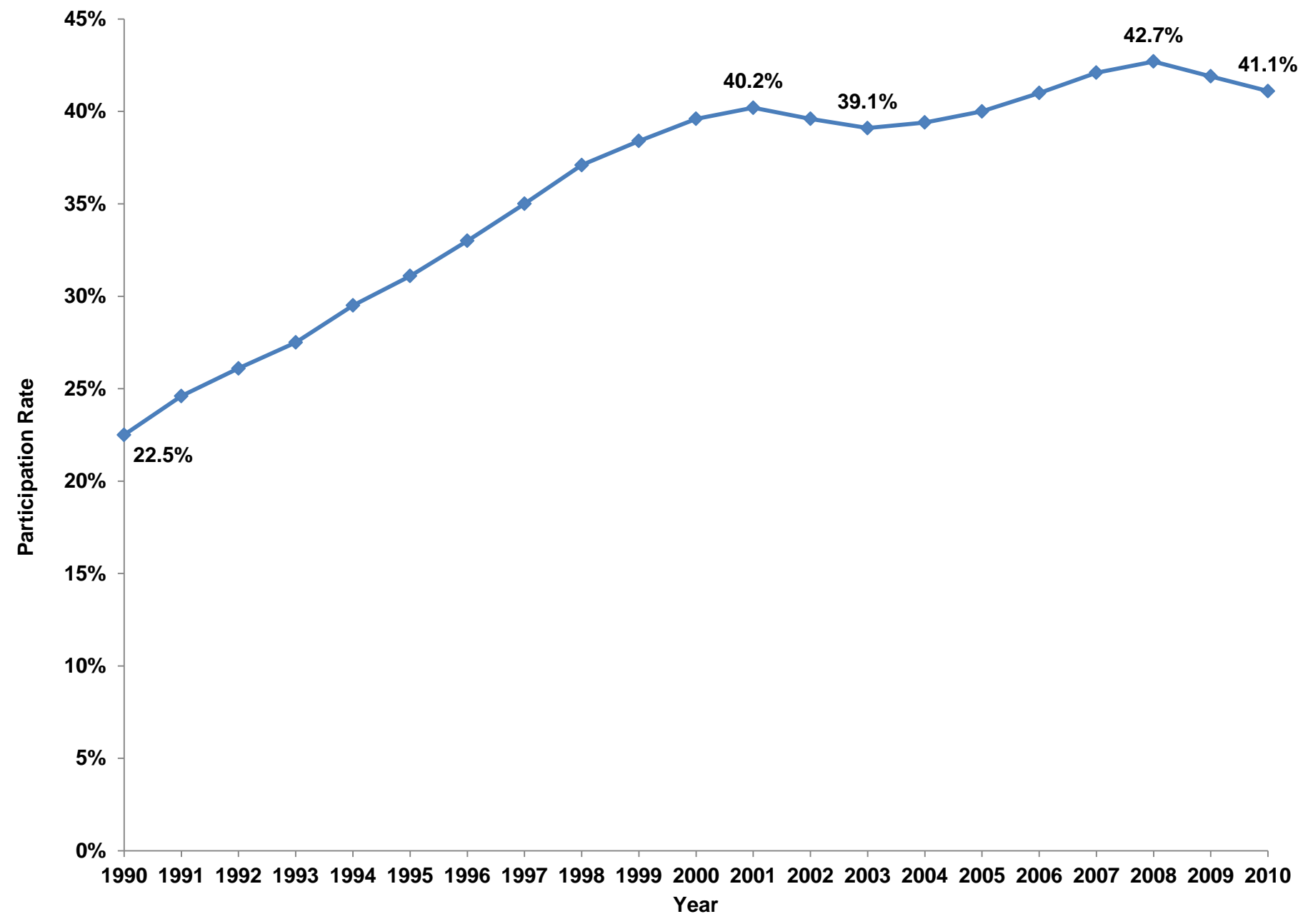

Source: Authors' tabulations of the 1996, 2001, 2004, 2008 SIPP data matched to the Social Security Administration's Detailed Earnings Record (DER). 
Figure 3. Participation Rate among Wage and Salary Workers by Age and Year

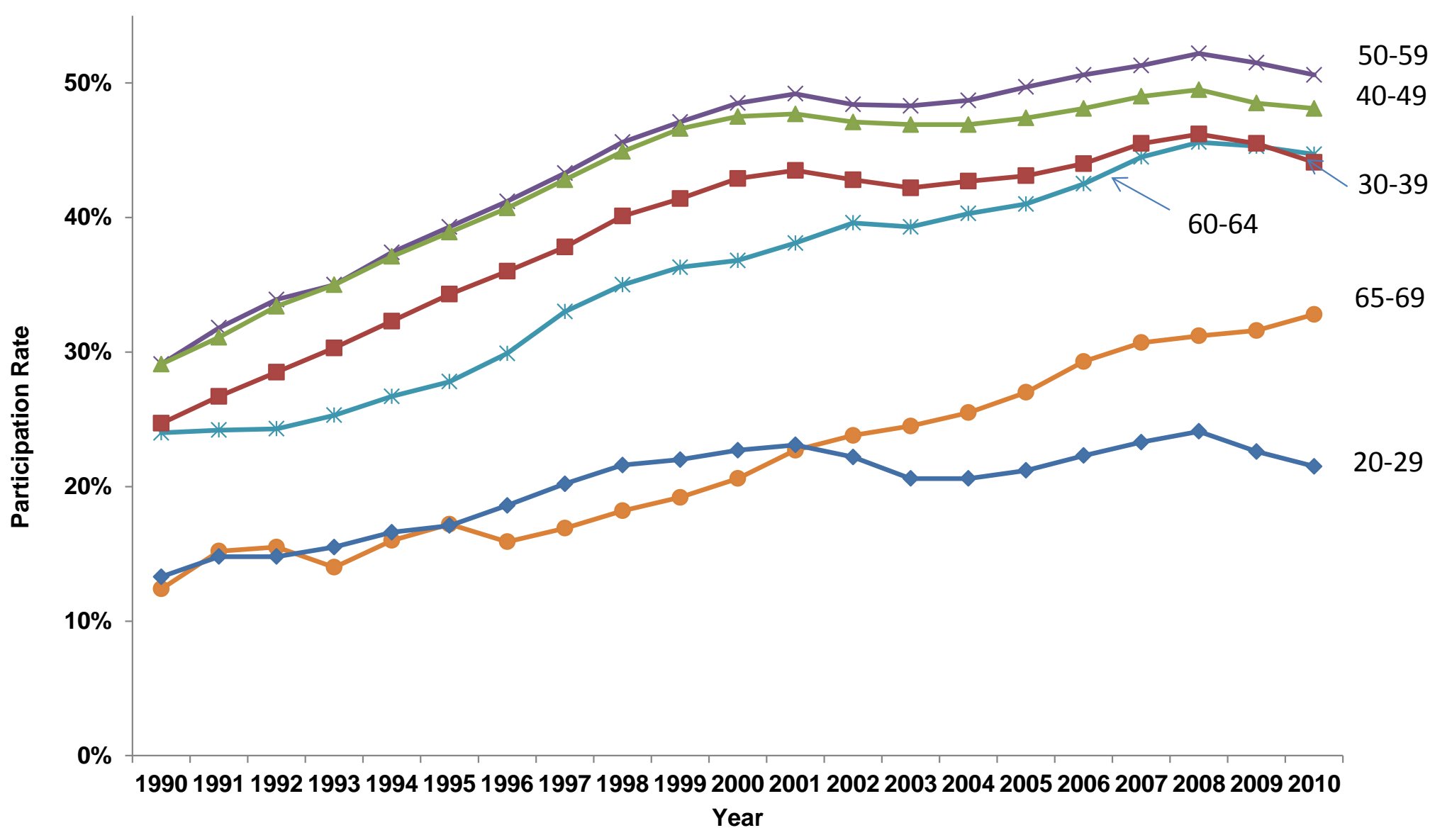

Source: Authors' tabulations of the 1996, 2001, 2004, 2008 SIPP data matched to the Social Security Administration's Detailed Earnings Record (DER). 
Figure 4. Participation Rate among Wage and Salary Workers by Age and Cohort

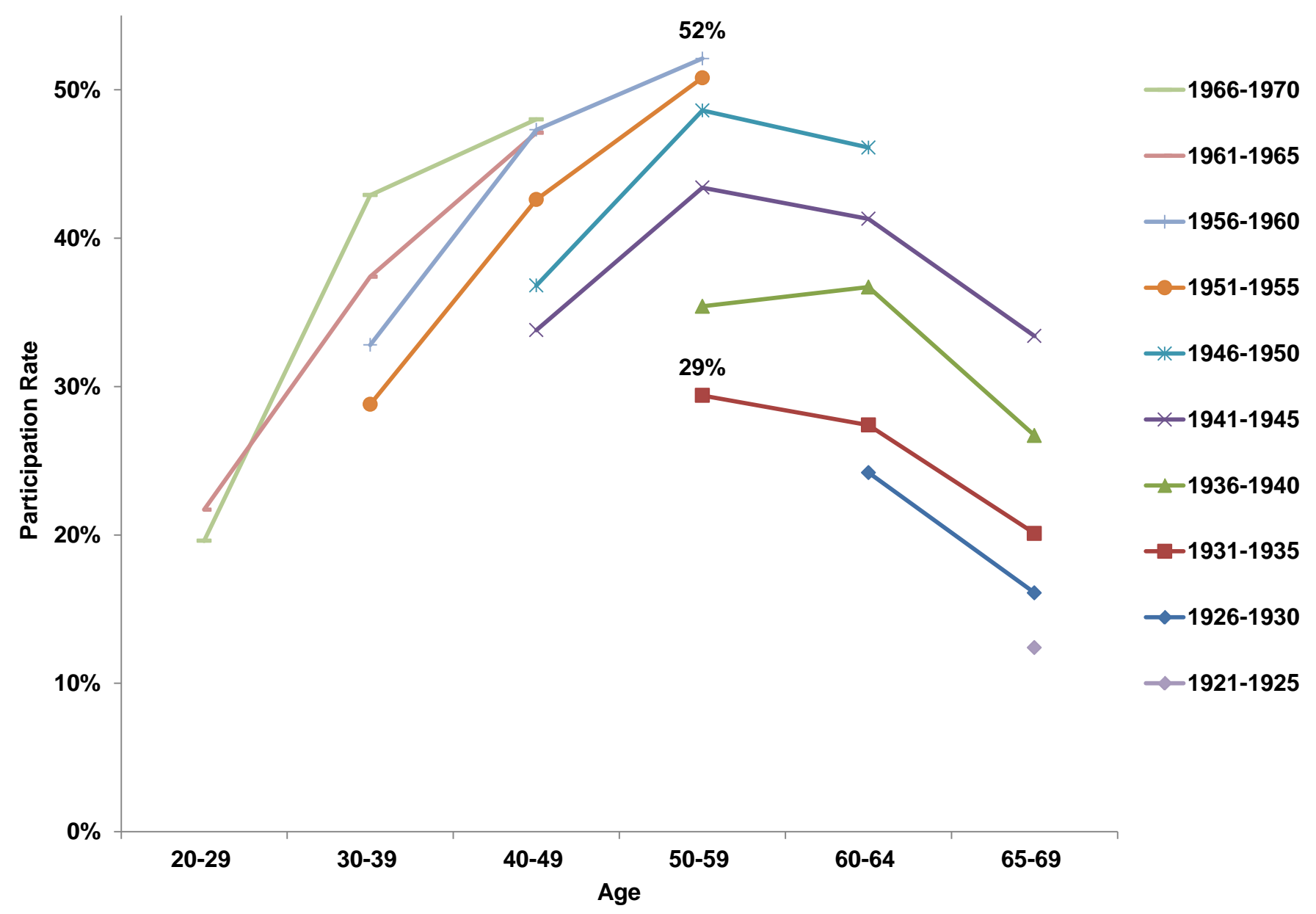

Source: Authors' tabulations of the 1996, 2001, 2004, 2008 SIPP data matched to the Social Security Administration's Detailed Earnings Record (DER). 
Figure 5. Distribution of DC Offer and Participation among Wage and Salary Workers Ages 20 to 69 by Age in 2006

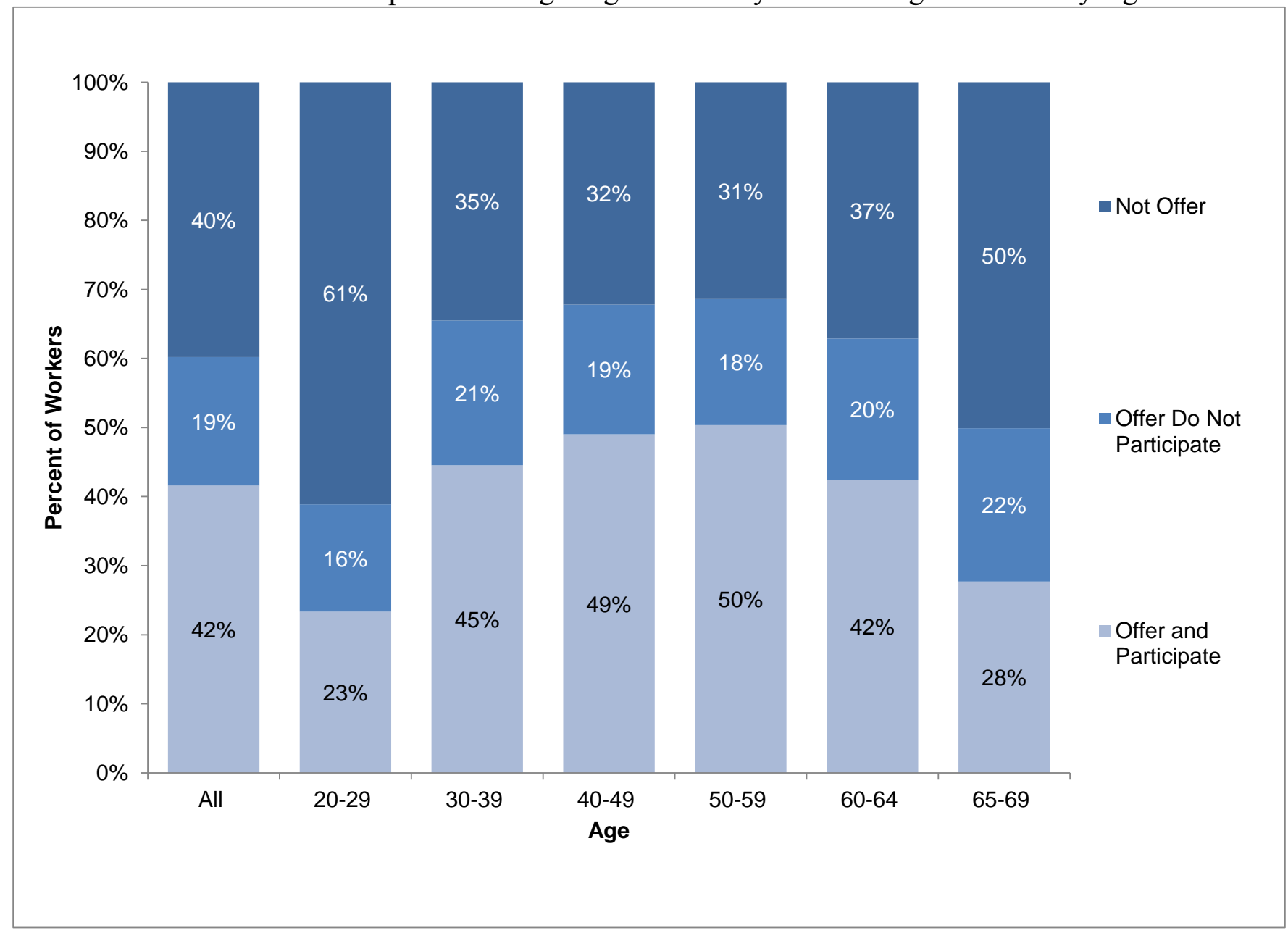

Source: Authors' tabulations of the 1996, 2001, 2004, 2008 SIPP data matched to the Social Security Administration's Detailed Earnings Record (DER). 
Figure 6. Participation Rate among Wage and Salary Workers Offered a DC Plan by Age and Year

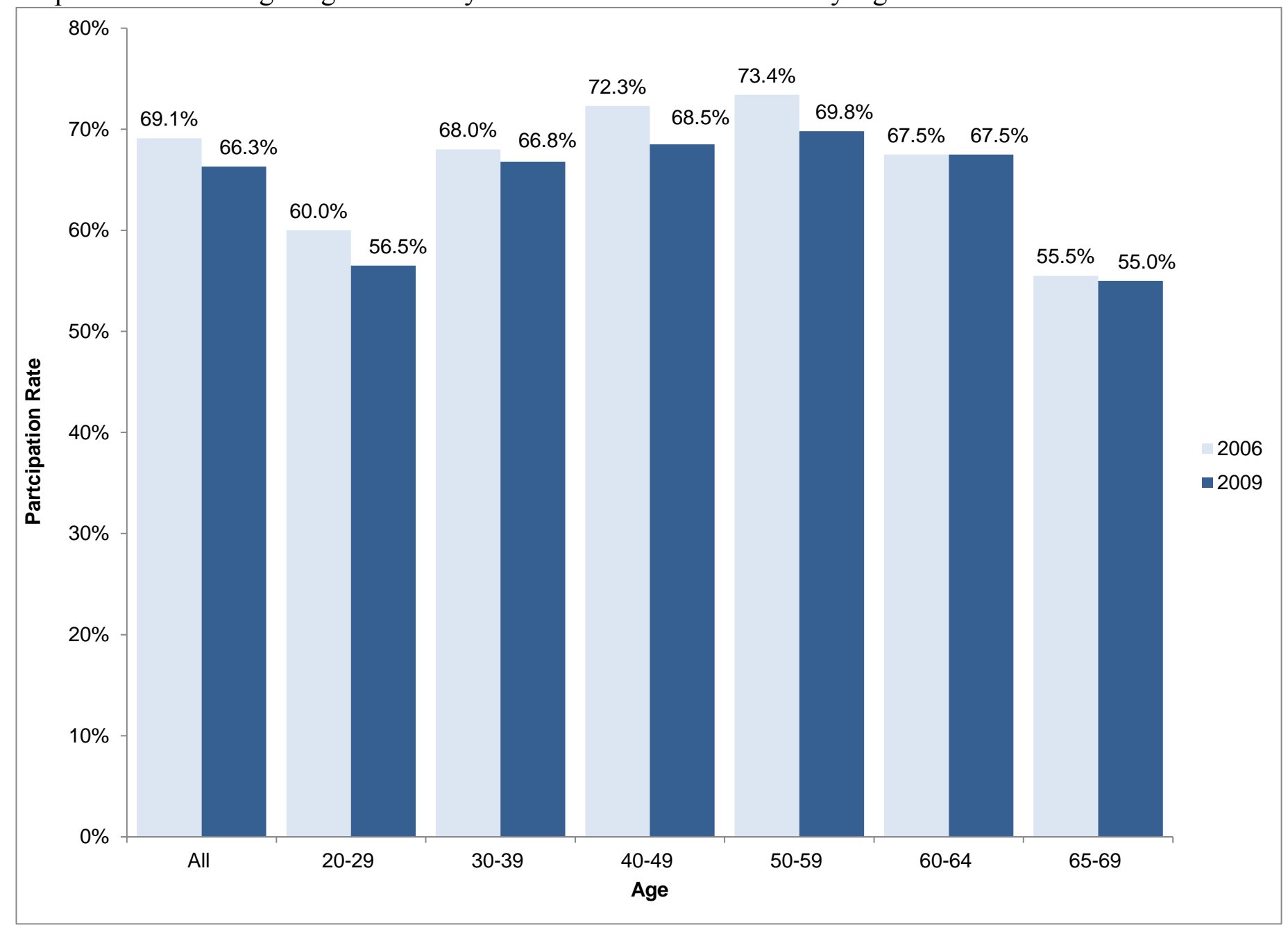

Source: Authors' tabulations of the 1996, 2001, 2004, 2008 SIPP data matched to the Social Security Administration's Detailed Earnings Record (DER). 
Figure 7. Percent Change in DC Contribution Amount among Wage and Salary Participants Ages 20 to 69, by Year

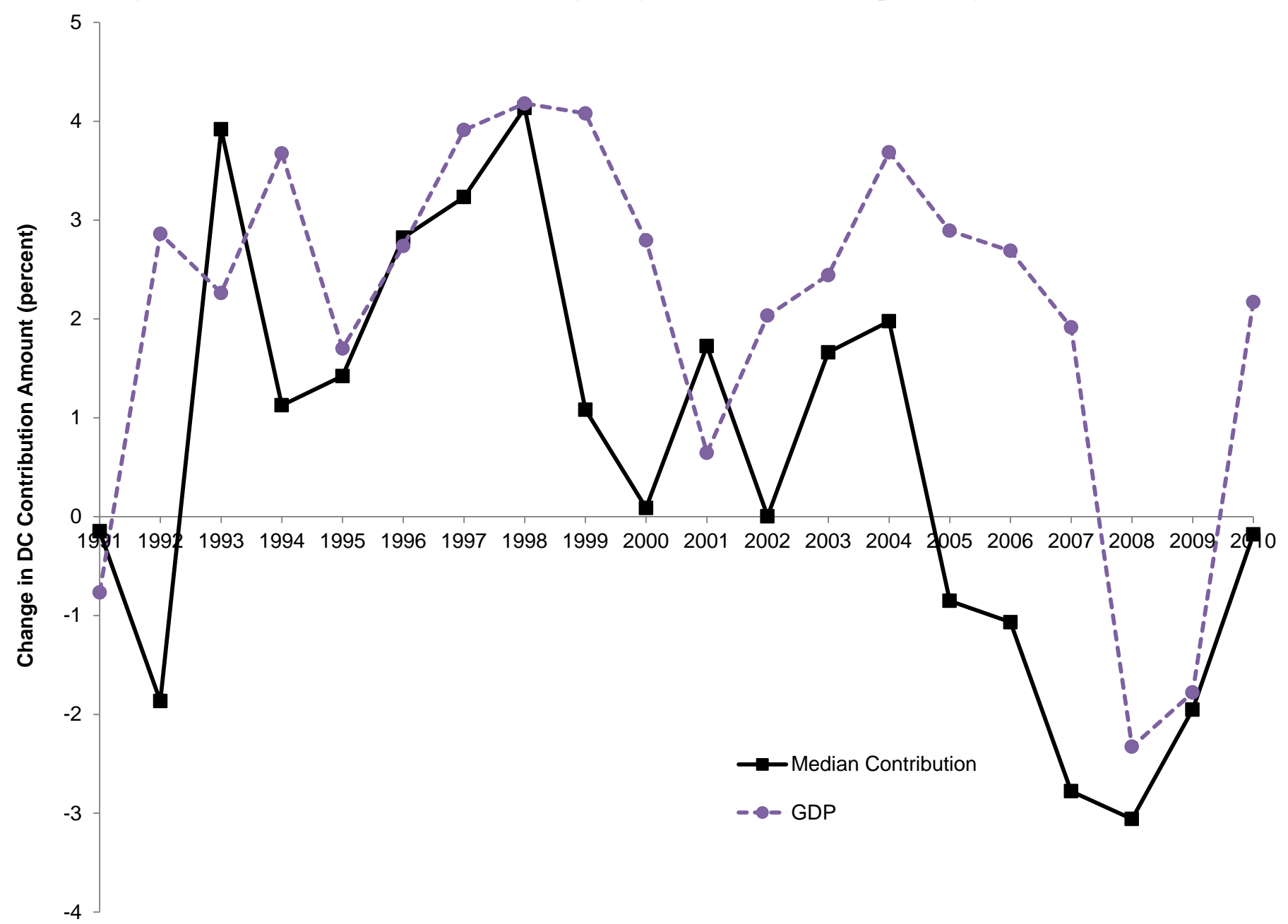

Source: Authors' tabulations of the 1996, 2001, 2004, 2008 SIPP data matched to the Social Security Administration's Detailed Earnings Record (DER). 
Figure 8. Median DC Contribution Amount (and Percent Change) among Wage and Salary Participants, by Age and Year

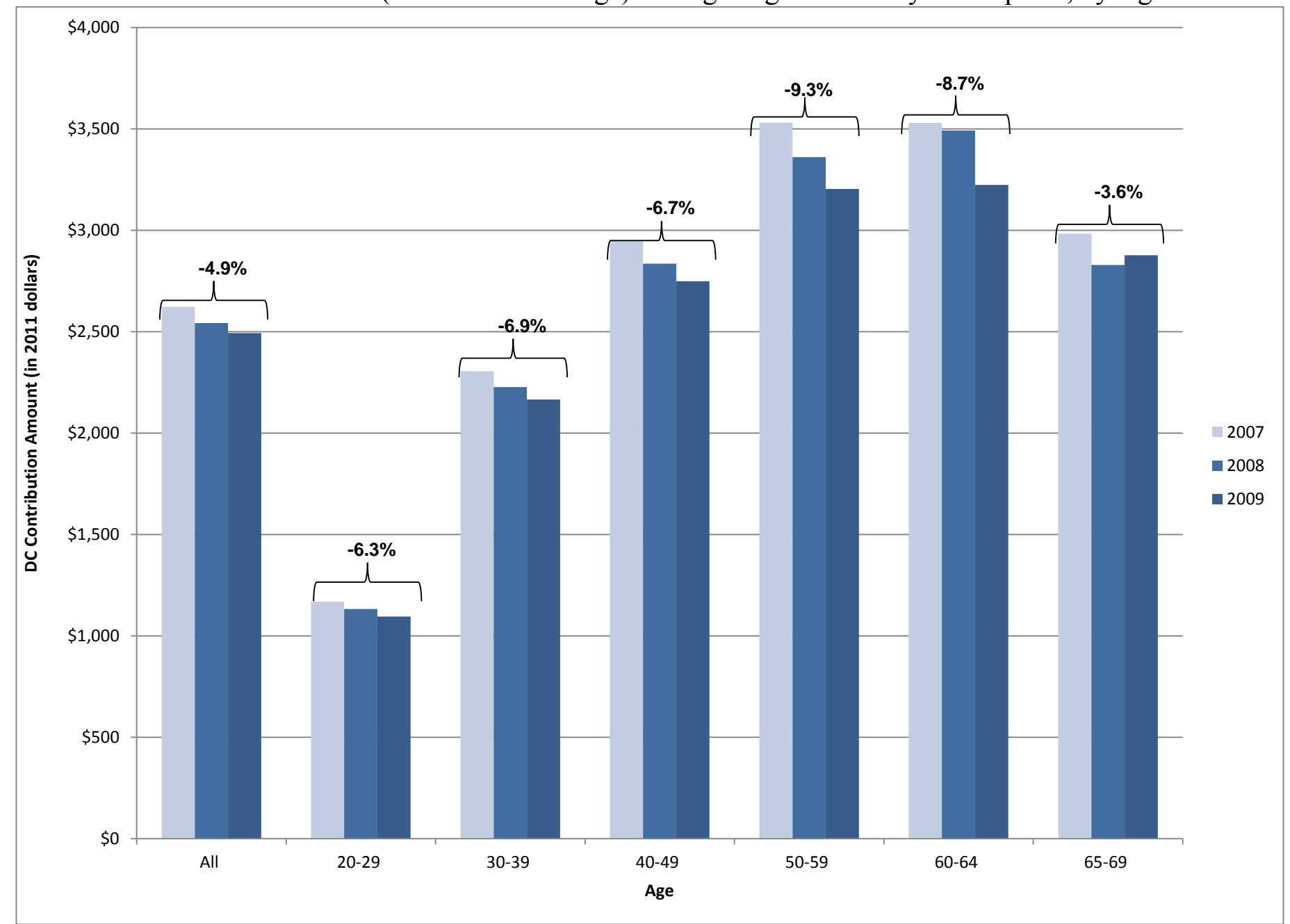

Source: Authors' tabulations of the 1996, 2001, 2004, 2008 SIPP data matched to the Social Security Administration's Detailed Earnings Record (DER). 
Figure 9. Median DC Contribution Amount (and Percent Change) among Wage and Salary Participants, by Age and Year

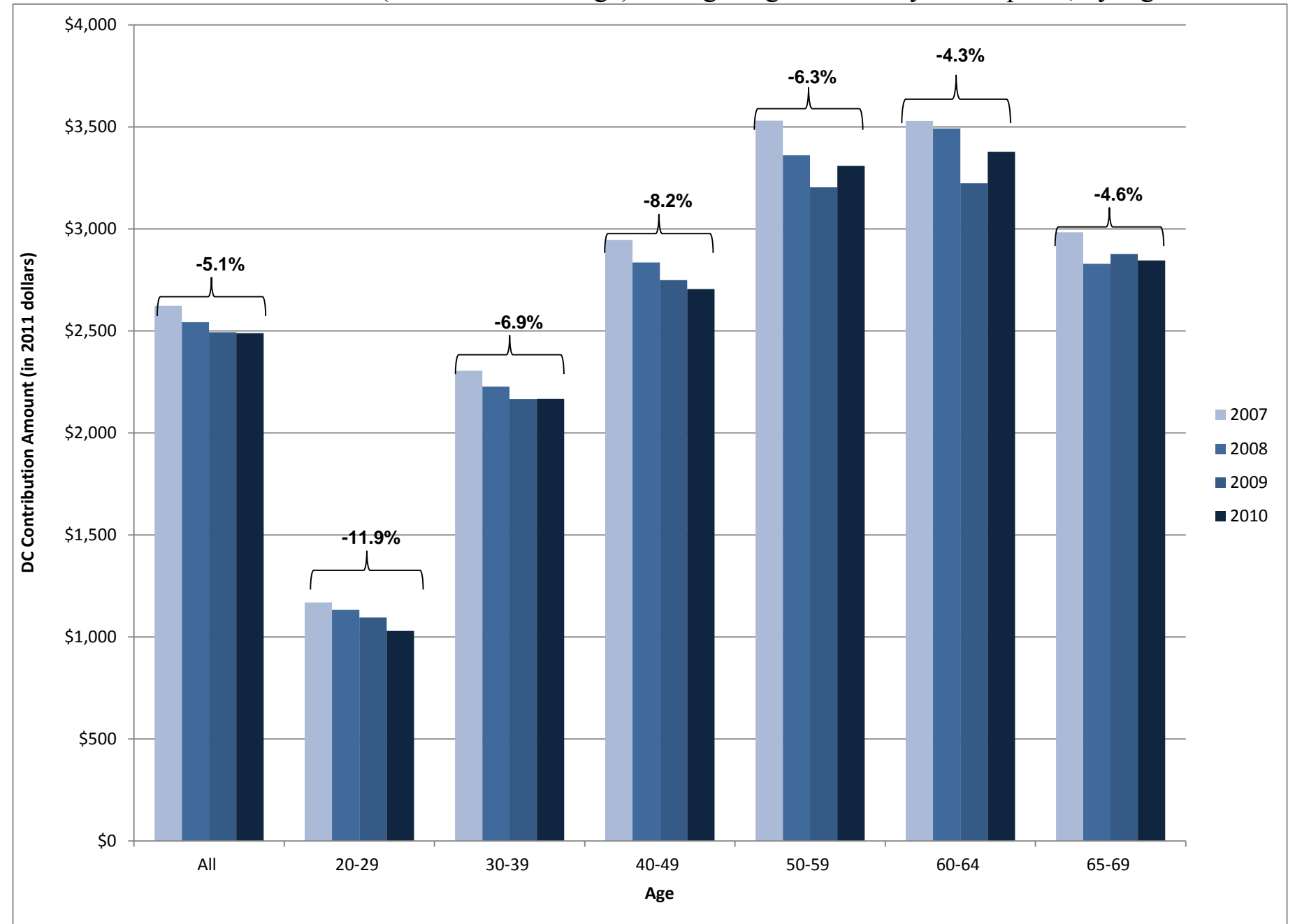

Source: Authors' tabulations of the 1996, 2001, 2004, 2008 SIPP data matched to the Social Security Administration's Detailed Earnings Record (DER). 
Figure 10. Percent Loss in Median DC Contribution Amount among Wage and Salary Participants Ages 20 to 69, by Earnings

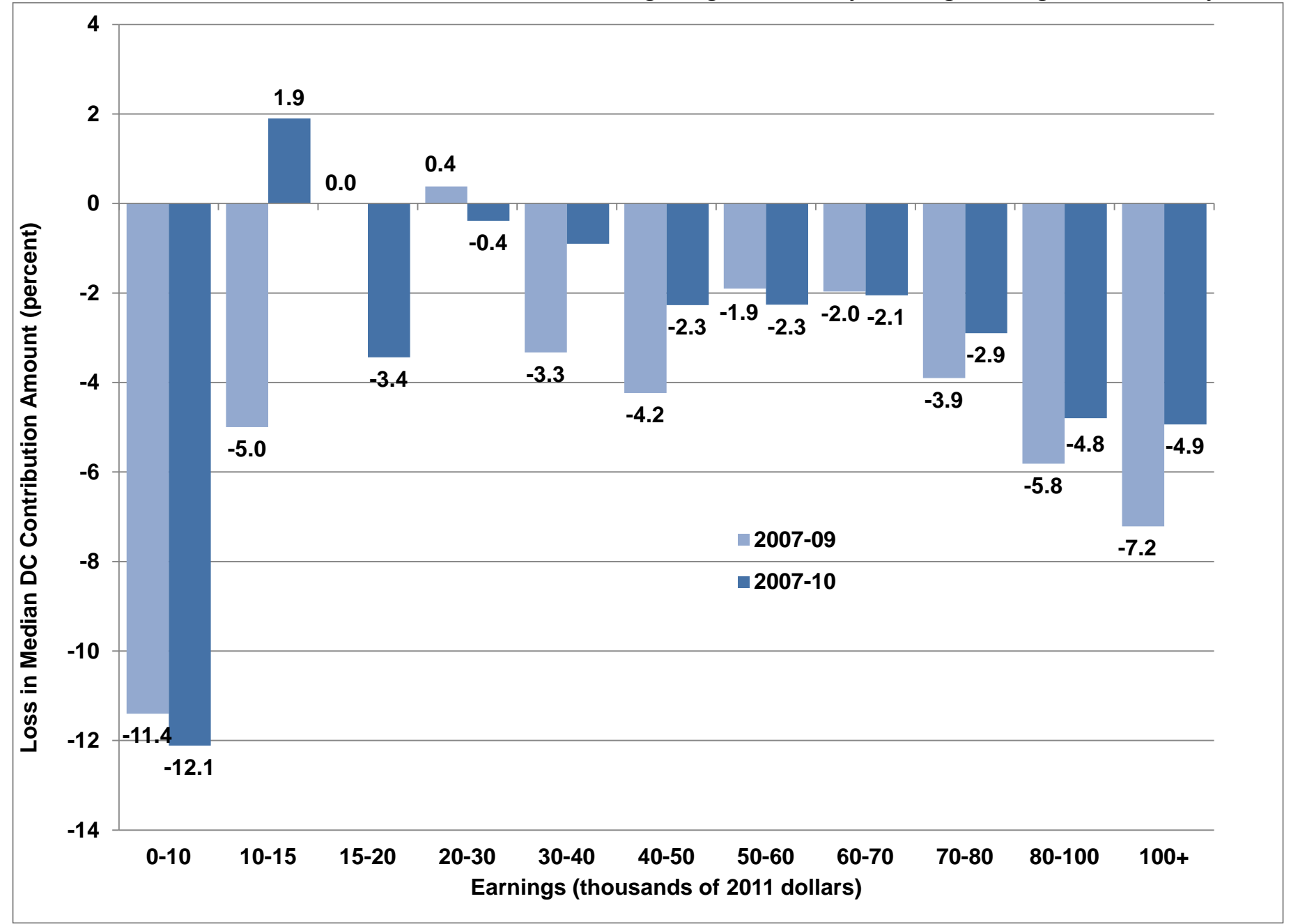

Source: Authors' tabulations of the 1996, 2001, 2004, 2008 SIPP data matched to the Social Security Administration's Detailed Earnings Record (DER). 
Figure 11. Median DC Contribution Rate (and Percent Drop) among Wage and Salary Participants, by Age and Year

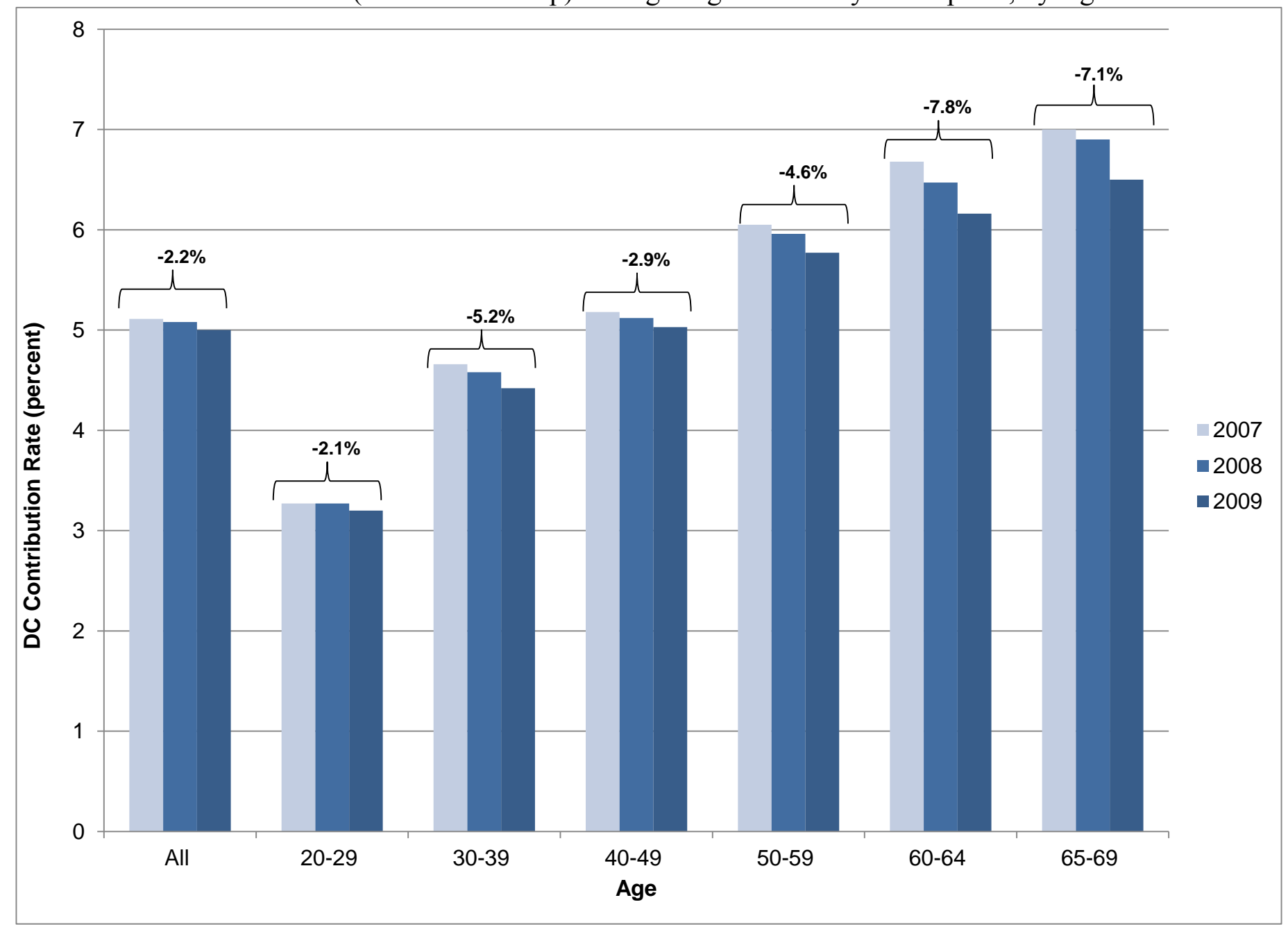

Source: Authors' tabulations of the 1996, 2001, 2004, 2008 SIPP data matched to the Social Security Administration's Detailed Earnings Record (DER). 
Figure 12. Median DC Contribution Rate (and Percent Drop) among Wage and Salary Participants, by Age and Year

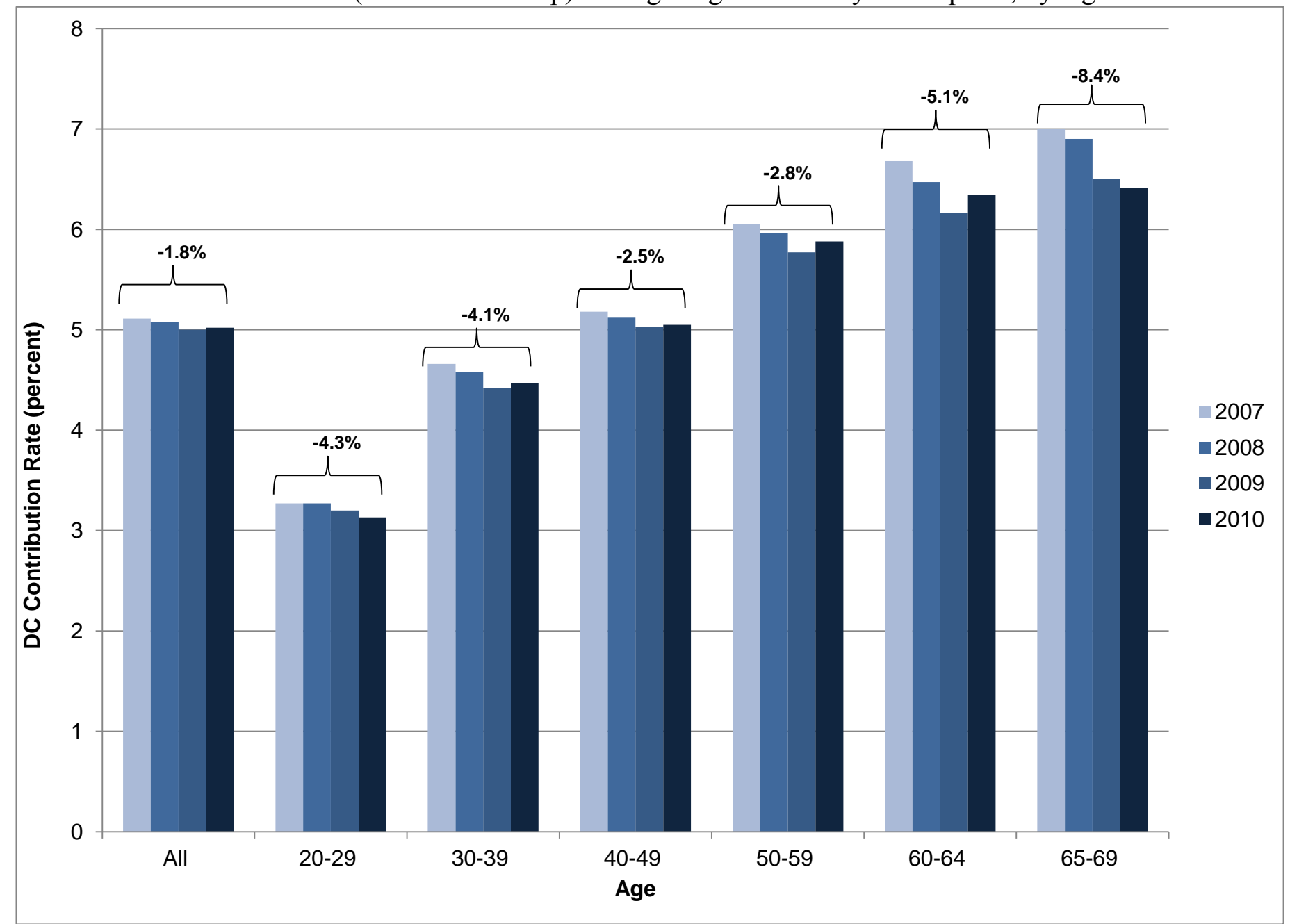

Source: Authors' tabulations of the 1996, 2001, 2004, 2008 SIPP data matched to the Social Security Administration's Detailed Earnings Record (DER). 
Figure 13. Percent Decline in Median DC Contribution Rate among Wage and Salary Participants Ages 20 to 69, by Earnings

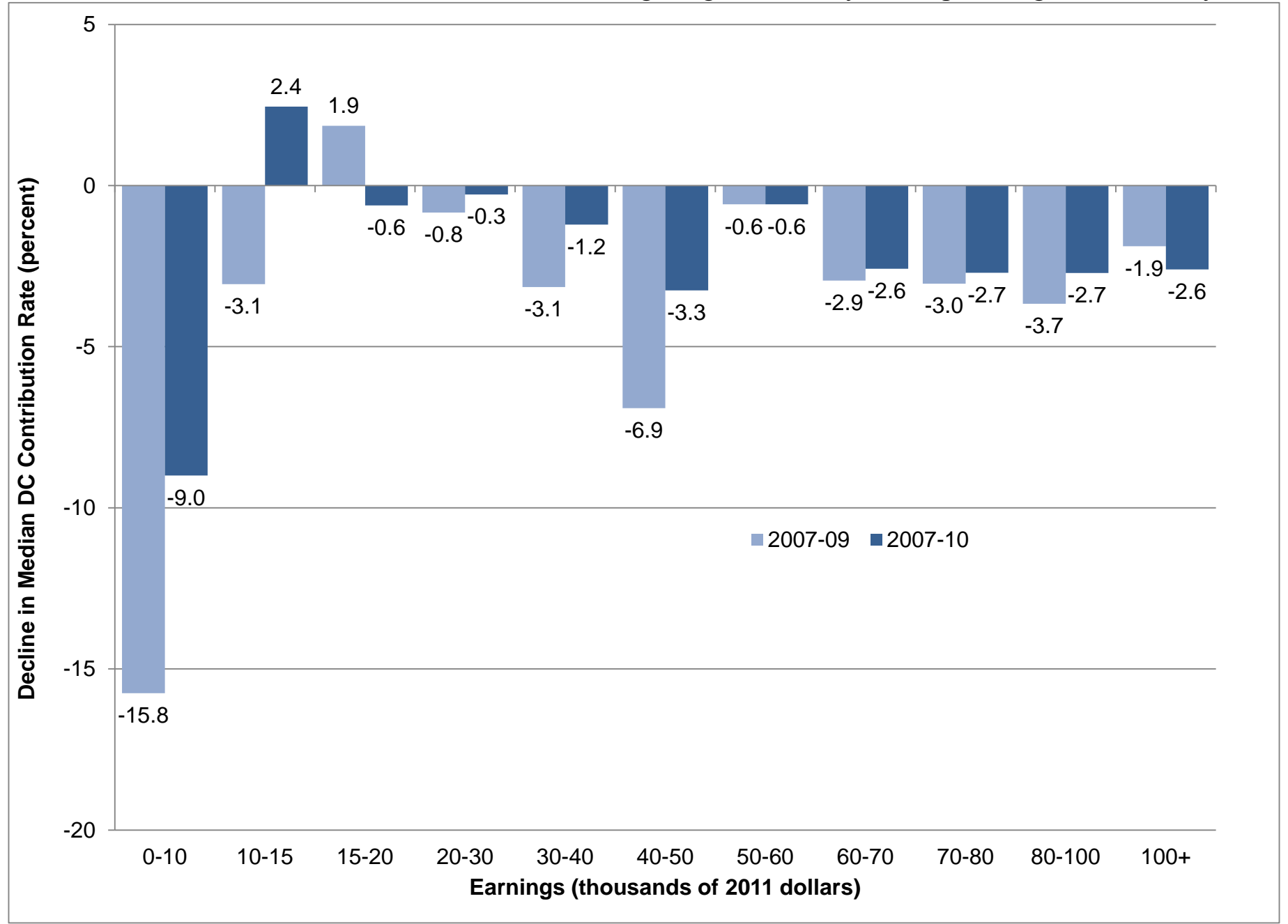

Source: Authors' tabulations of the 1996, 2001, 2004, 2008 SIPP data matched to the Social Security Administration's Detailed Earnings Record (DER). 
Figure 14. Wage and Salary Worker Participation Logistic Regression Parameter Estimates for Year by Estimation Sample

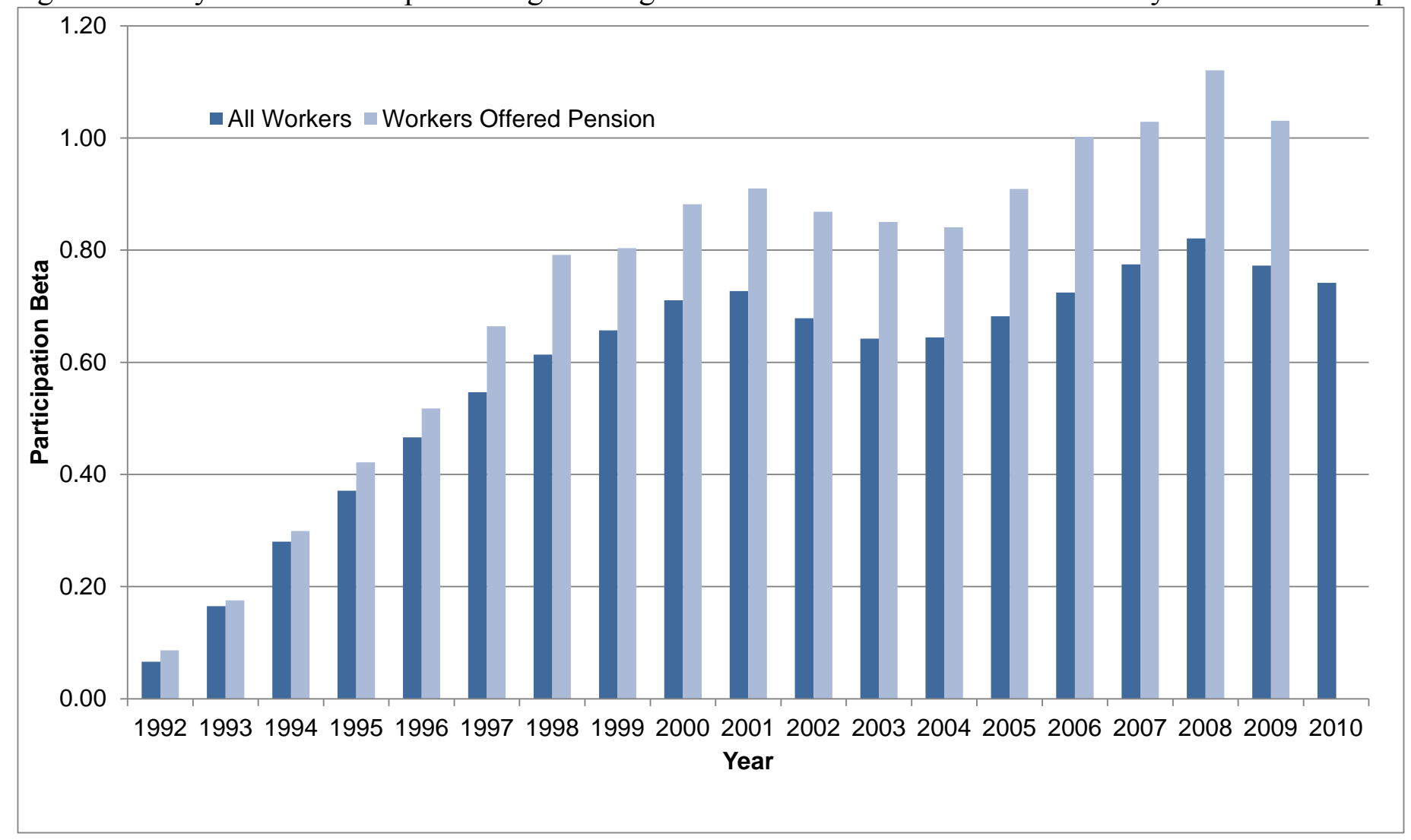

Source: Authors' tabulations of the 1996, 2001, 2004, 2008 SIPP data matched to the Social Security Administration's Detailed Earnings Record (DER). 
Figure 15. Wage and Salary Worker Contribution Amount OLS Regression Parameter Estimates for Year by Estimation Sample $(\$ 2011)$

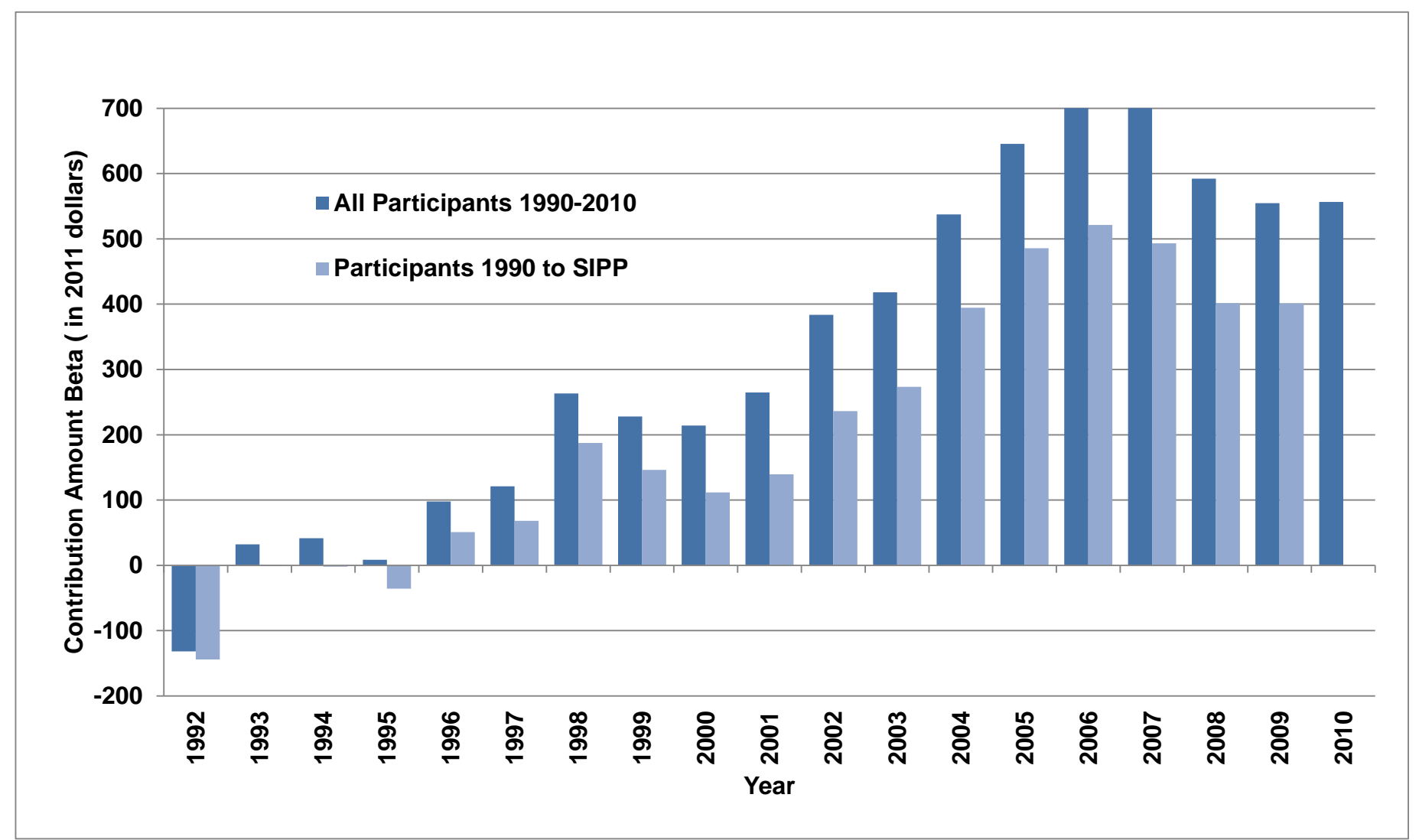

Source: Authors' tabulations of the 1996, 2001, 2004, 2008 SIPP data matched to the Social Security Administration's Detailed Earnings Record (DER). 
Figure 16. Percentage of Wage and Salary Workers Investing Current 401(k) Contributions, by Investment Type and Year

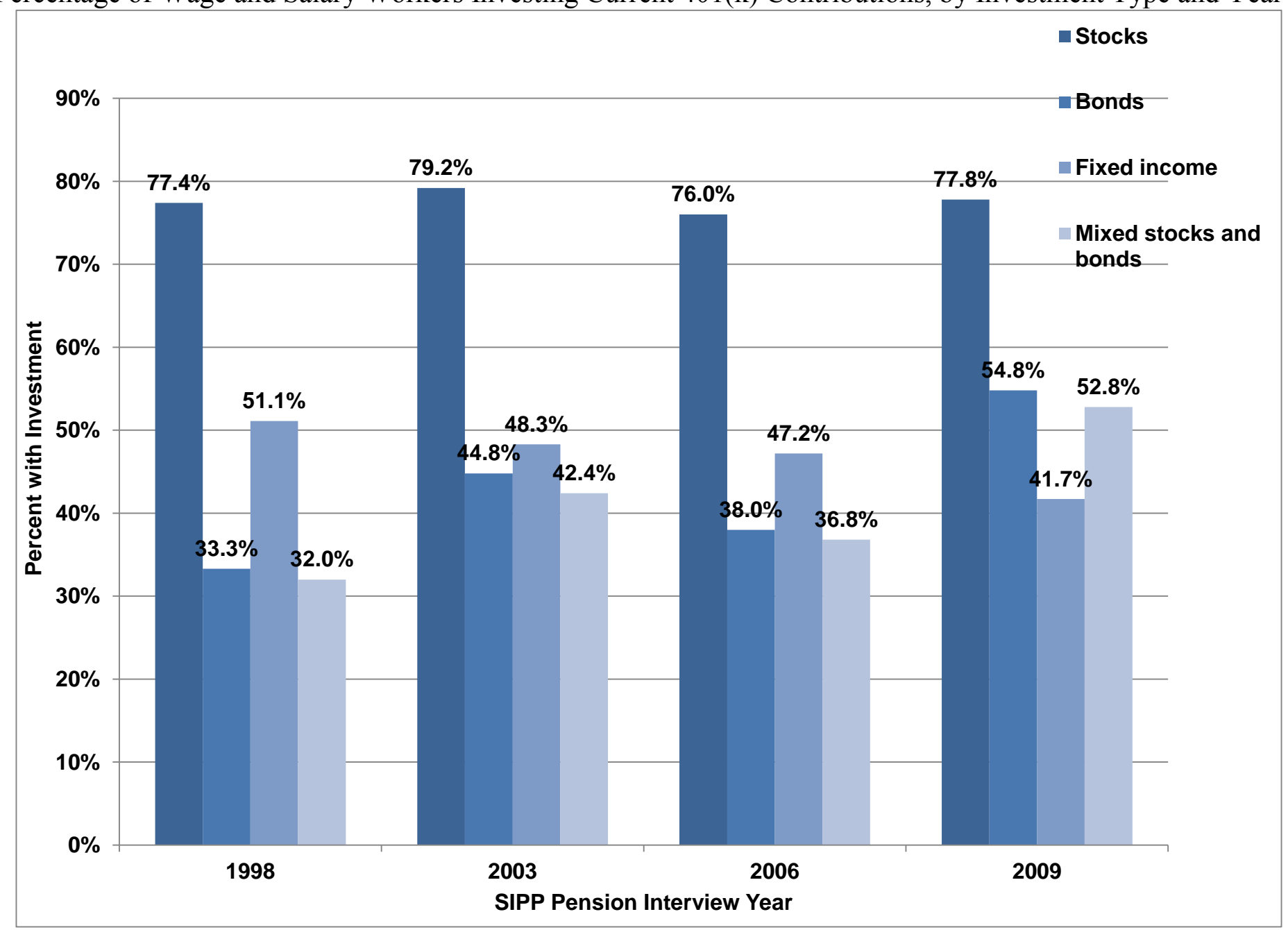

Source: Authors' tabulations of the 1996, 2001, 2004, 2008 SIPP pension topical modules. 
Figure 17. Asset Allocation among Current 401(k) Contributions, by Year

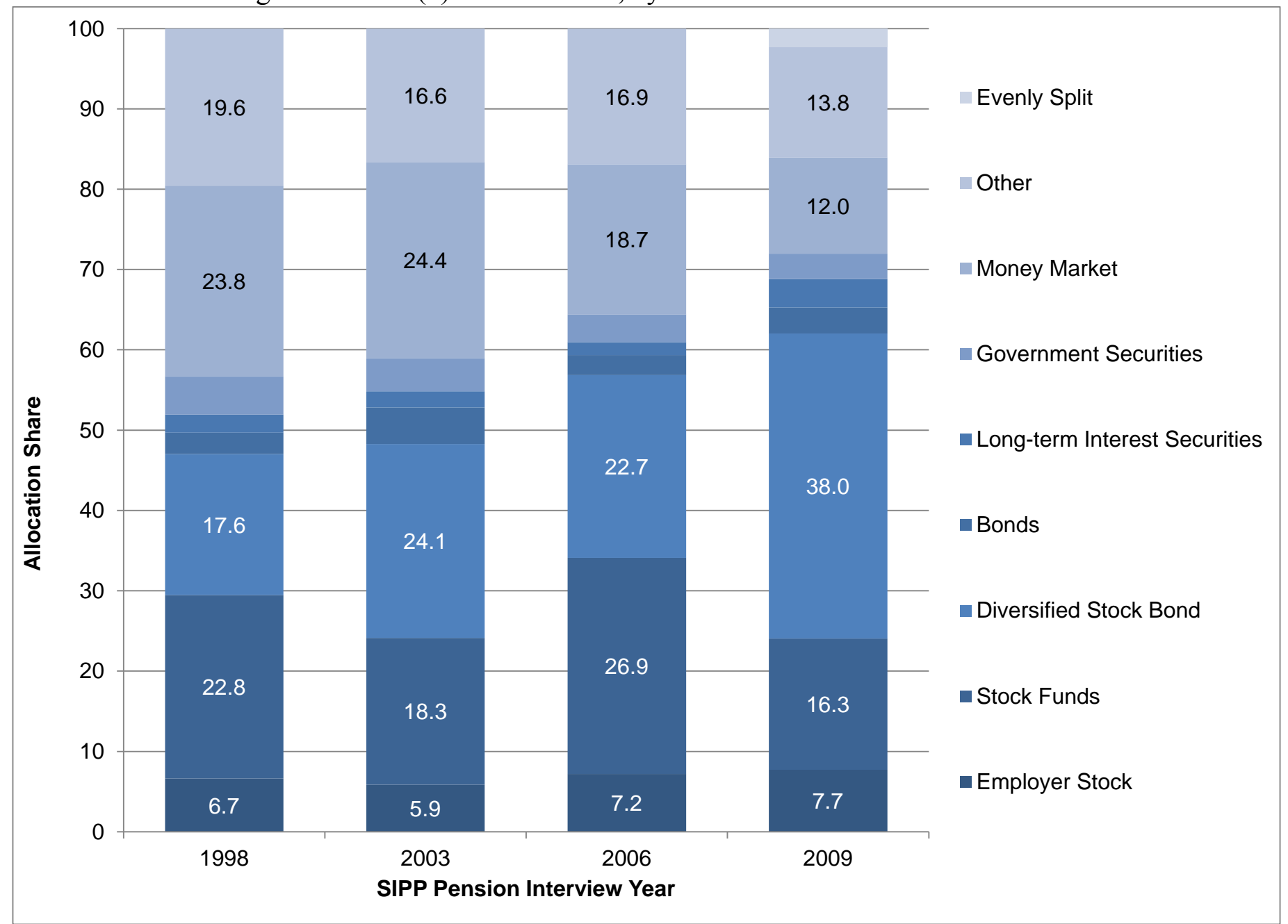

Source: Authors' tabulations of the 1996, 2001, 2004, 2008 SIPP pension topical modules. 
Figure 18. Percentage of Adults Investing Current Retirement Account Balances, by Investment Type and Year

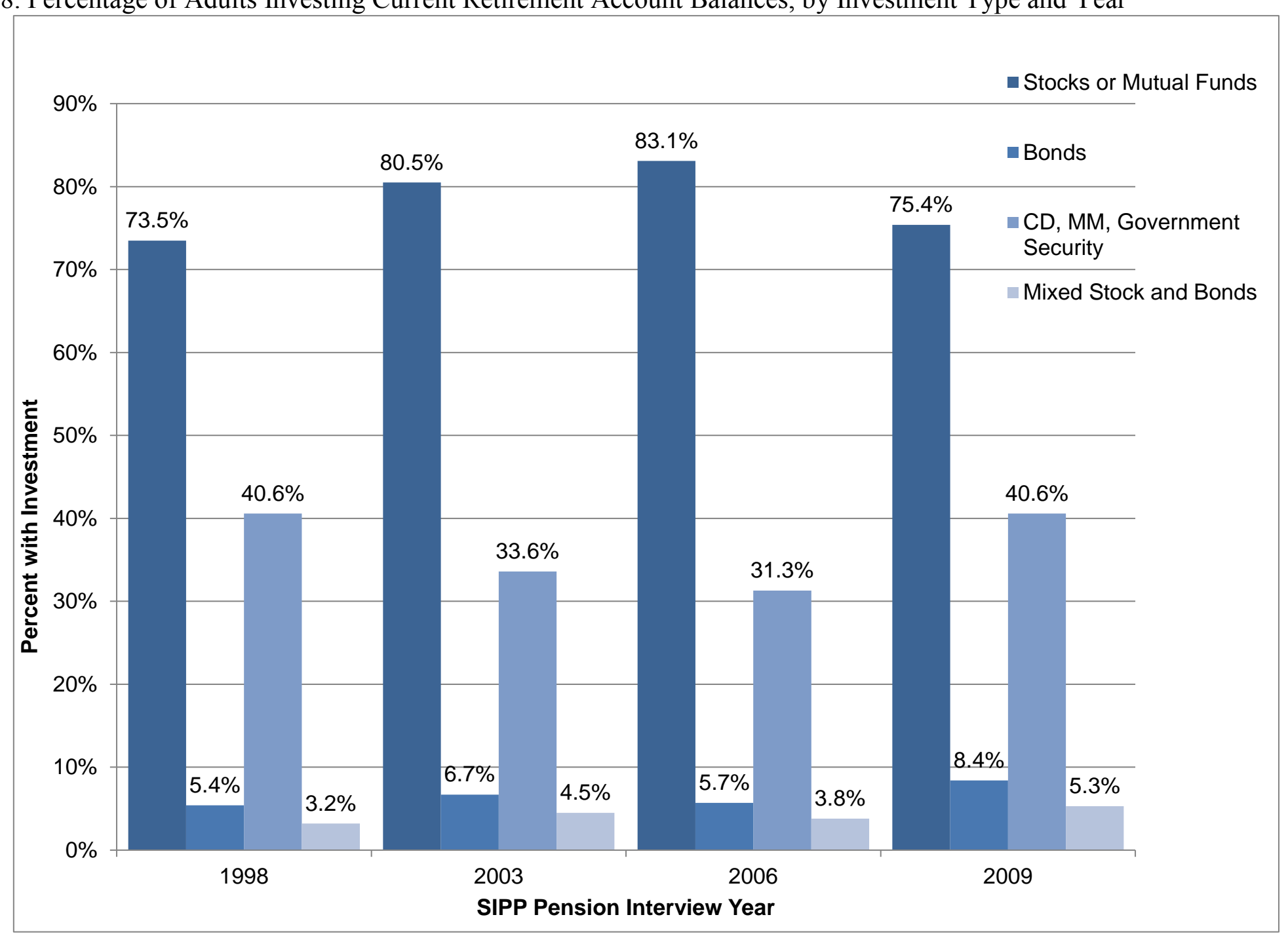

Source: Authors' tabulations of the 1996, 2001, 2004, 2008 SIPP wealth topical modules (see text). 
Table 1. Median Contribution Amount for Wage and Salary Participants Ages 20 to 69, by Year and Age (in 2011 dollars)

\begin{tabular}{llllllll}
\hline & \multicolumn{7}{c}{ Age } \\
\cline { 2 - 7 } Year & All & $\mathbf{2 0 - 2 9}$ & $\mathbf{3 0 - 3 9}$ & $\mathbf{4 0 - 4 9}$ & $\mathbf{5 0 - 5 9}$ & $\mathbf{6 0 - 6 4}$ & $\mathbf{6 5 - 6 9}$ \\
\hline $\mathbf{1 9 9 0}$ & 2,233 & 1,247 & 2,007 & 2,722 & 3,606 & 4,028 & 3,595 \\
$\mathbf{1 9 9 1}$ & 2,229 & 1,293 & 1,980 & 2,644 & 3,545 & 3,717 & 3,259 \\
$\mathbf{1 9 9 2}$ & 2,188 & 1,179 & 1,957 & 2,646 & 3,574 & 3,849 & 2,405 \\
$\mathbf{1 9 9 3}$ & 2,273 & 1,209 & 2,021 & 2,730 & 3,684 & 3,429 & 2,473 \\
$\mathbf{1 9 9 4}$ & 2,299 & 1,227 & 2,056 & 2,721 & 3,605 & 3,300 & 2,550 \\
$\mathbf{1 9 9 5}$ & 2,332 & 1,200 & 2,090 & 2,693 & 3,496 & 3,303 & 2,622 \\
$\mathbf{1 9 9 6}$ & 2,398 & 1,236 & 2,183 & 2,724 & 3,502 & 3,450 & 2,731 \\
$\mathbf{1 9 9 7}$ & 2,475 & 1,247 & 2,251 & 2,761 & 3,570 & 3,383 & 2,584 \\
$\mathbf{1 9 9 8}$ & 2,577 & 1,377 & 2,362 & 2,875 & 3,643 & 3,608 & 3,201 \\
$\mathbf{1 9 9 9}$ & 2,605 & 1,386 & 2,394 & 2,929 & 3,529 & 3,599 & 2,601 \\
$\mathbf{2 0 0 0}$ & 2,608 & 1,394 & 2,419 & 2,901 & 3,545 & 3,287 & 2,362 \\
$\mathbf{2 0 0 1}$ & 2,653 & 1,393 & 2,443 & 2,942 & 3,482 & 3,448 & 2,403 \\
$\mathbf{2 0 0 2}$ & 2,653 & 1,386 & 2,448 & 2,993 & 3,570 & 3,402 & 2,520 \\
$\mathbf{2 0 0 3}$ & 2,697 & 1,392 & 2,407 & 2,958 & 3,518 & 3,319 & 2,712 \\
$\mathbf{2 0 0 4}$ & 2,750 & 1,290 & 2,402 & 3,042 & 3,603 & 3,570 & 2,974 \\
$\mathbf{2 0 0 5}$ & 2,727 & 1,273 & 2,392 & 2,990 & 3,597 & 3,645 & 3,074 \\
$\mathbf{2 0 0 6}$ & 2,698 & 1,236 & 2,360 & 2,978 & 3,577 & 3,580 & 2,922 \\
$\mathbf{2 0 0 7}$ & 2,623 & 1,168 & 2,304 & 2,946 & 3,530 & 3,529 & 2,983 \\
$\mathbf{2 0 0 8}$ & 2,542 & 1,132 & 2,226 & 2,835 & 3,360 & 3,492 & 2,829 \\
$\mathbf{2 0 0 9}$ & 2,493 & 1,095 & 2,165 & 2,748 & 3,203 & 3,224 & 2,877 \\
$\mathbf{2 0 1 0}$ & 2,488 & 1,030 & 2,166 & 2,705 & 3,309 & 3,378 & 2,845 \\
\hline
\end{tabular}

Source: Authors' tabulations of the 1996, 2001, 2004, 2008 SIPP data matched to the Social Security Administration's Detailed Earnings Record (DER).

Note: Contributions are based on positive deferred contributions on the DER from 1990 to 2010. 
Table 2. Change in Median Contribution Amount for Wage and Salary Participants Ages 20 to 69, by Year and Age (percent)

\begin{tabular}{lccccccc}
\hline & \multicolumn{7}{c}{ Age } \\
\cline { 2 - 8 } Year & All & $\mathbf{2 0 - 2 9}$ & $\mathbf{3 0 - 3 9}$ & $\mathbf{4 0 - 4 9}$ & $\mathbf{5 0 - 5 9}$ & $\mathbf{6 0 - 6 4}$ & $\mathbf{6 5 - 6 9}$ \\
\hline $\mathbf{1 9 9 1}$ & -0.1 & 3.7 & -1.3 & -2.9 & -1.7 & -7.7 & -9.3 \\
$\mathbf{1 9 9 2}$ & -1.9 & -8.8 & -1.2 & 0.1 & 0.8 & 3.6 & -26.2 \\
$\mathbf{1 9 9 3}$ & 3.9 & 2.6 & 3.3 & 3.2 & 3.1 & -10.9 & 2.8 \\
$\mathbf{1 9 9 4}$ & 1.1 & 1.4 & 1.7 & -0.3 & -2.1 & -3.8 & 3.1 \\
$\mathbf{1 9 9 5}$ & 1.4 & -2.2 & 1.7 & -1.0 & -3.0 & 0.1 & 2.8 \\
$\mathbf{1 9 9 6}$ & 2.8 & 3.0 & 4.4 & 1.2 & 0.2 & 4.4 & 4.2 \\
$\mathbf{1 9 9 7}$ & 3.2 & 0.8 & 3.1 & 1.3 & 1.9 & -1.9 & -5.4 \\
$\mathbf{1 9 9 8}$ & 4.1 & 10.5 & 4.9 & 4.1 & 2.1 & 6.7 & 23.9 \\
$\mathbf{1 9 9 9}$ & 1.1 & 0.6 & 1.4 & 1.9 & -3.1 & -0.2 & -18.7 \\
$\mathbf{2 0 0 0}$ & 0.1 & 0.6 & 1.1 & -1.0 & 0.4 & -8.7 & -9.2 \\
$\mathbf{2 0 0 1}$ & 1.7 & -0.1 & 1.0 & 1.4 & -1.8 & 4.9 & 1.8 \\
$\mathbf{2 0 0 2}$ & 0.0 & -0.5 & 0.2 & 1.7 & 2.5 & -1.3 & 4.9 \\
$\mathbf{2 0 0 3}$ & 1.7 & 0.4 & -1.7 & -1.2 & -1.4 & -2.4 & 7.6 \\
$\mathbf{2 0 0 4}$ & 2.0 & -7.3 & -0.2 & 2.9 & 2.4 & 7.6 & 9.7 \\
$\mathbf{2 0 0 5}$ & -0.9 & -1.3 & -0.4 & -1.7 & -0.2 & 2.1 & 3.4 \\
$\mathbf{2 0 0 6}$ & -1.1 & -2.9 & -1.3 & -0.4 & -0.6 & -1.8 & -4.9 \\
$\mathbf{2 0 0 7}$ & -2.8 & -5.5 & -2.4 & -1.1 & -1.3 & -1.4 & 2.1 \\
$\mathbf{2 0 0 8}$ & -3.1 & -3.1 & -3.4 & -3.8 & -4.8 & -1.1 & -5.2 \\
$\mathbf{2 0 0 9}$ & -2.0 & -3.3 & -2.7 & -3.1 & -4.7 & -7.7 & 1.7 \\
$\mathbf{2 0 1 0}$ & -0.2 & -5.9 & 0.1 & -1.6 & 3.3 & 4.8 & -1.1 \\
& & & & & & & \\
$\mathbf{2 0 0 7 - 0 9}$ & -4.9 & -6.3 & -6.0 & -6.7 & -9.3 & -8.7 & -3.6 \\
$\mathbf{2 0 0 7 - 1 0}$ & -5.1 & -11.9 & -6.0 & -8.2 & -6.3 & -4.3 & -4.6 \\
\hline & & & & & & & \\
\hline & & & & & & & \\
\hline
\end{tabular}

Source: Authors' tabulations of the 1996, 2001, 2004, 2008 SIPP data matched to the Social Security Administration's Detailed Earnings Record (DER).

Note: Contributions are based on positive deferred contributions on the DER from 1990 to 2010 . 
Table 3. Median Contribution Amount for Wage and Salary Participants Ages 20 to 69, by Year and Own Earnings (in 2011 dollars)

\begin{tabular}{|c|c|c|c|c|c|c|c|c|c|c|c|c|}
\hline \multirow[b]{2}{*}{ Year } & \multicolumn{12}{|c|}{ Own Earnings (thousands of 2011 dollars) } \\
\hline & All & $0-10$ & $10-15$ & $15-20$ & $20-30$ & $30-40$ & $40-50$ & $50-60$ & $60-70$ & $70-80$ & $80-100$ & $100+$ \\
\hline 1990 & 2,233 & 326 & 536 & 699 & 919 & 1,374 & 1,957 & 2,450 & 3,126 & 3,813 & 4,776 & 7,636 \\
\hline 1991 & 2,229 & 239 & 503 & 786 & 986 & 1,456 & 1,934 & 2,406 & 3,184 & 3,894 & 4,841 & 7,884 \\
\hline 1992 & 2,188 & 197 & 525 & 641 & 932 & 1,389 & 1,925 & 2,446 & 3,144 & 3,854 & 4,899 & 8,019 \\
\hline 1993 & 2,273 & 214 & 521 & 664 & 941 & 1,447 & 2,028 & 2,527 & 3,246 & 3,991 & 4,955 & 8,182 \\
\hline 1994 & 2,299 & 217 & 552 & 692 & 986 & 1,487 & 1,989 & 2,606 & 3,298 & 3,955 & 5,149 & 8,397 \\
\hline 1995 & 2,332 & 194 & 518 & 663 & 947 & 1,480 & 2,028 & 2,688 & 3,340 & 4,106 & 5,287 & 8,443 \\
\hline 1996 & 2,398 & 220 & 545 & 724 & 951 & 1,518 & 2,078 & 2,711 & 3,512 & 4,225 & 5,294 & 9,005 \\
\hline 1997 & 2,475 & 181 & 492 & 701 & 990 & 1,516 & 2,093 & 2,743 & 3,656 & 4,271 & 5,461 & 9,384 \\
\hline 1998 & 2,577 & 231 & 555 & 708 & 987 & 1,529 & 2,130 & 2,760 & 3,549 & 4,458 & 5,626 & 9,833 \\
\hline 1999 & 2,605 & 197 & 494 & 690 & 975 & 1,547 & 2,138 & 2,799 & 3,529 & 4,510 & 5,617 & 10,018 \\
\hline 2000 & 2,608 & 212 & 492 & 682 & 957 & 1,543 & 2,099 & 2,828 & 3,629 & 4,461 & 5,792 & 10,156 \\
\hline 2001 & 2,653 & 216 & 504 & 700 & 996 & 1,534 & 2,171 & 2,914 & 3,662 & 4,501 & 5,806 & 10,292 \\
\hline 2002 & 2,653 & 206 & 494 & 684 & 953 & 1,538 & 2,141 & 2,898 & 3,732 & 4,528 & 6,022 & 10,650 \\
\hline 2003 & 2,697 & 217 & 559 & 719 & 995 & 1,514 & 2,152 & 2,855 & 3,501 & 4,436 & 5,915 & 10,954 \\
\hline 2004 & 2,750 & 204 & 509 & 661 & 958 & 1,473 & 2,150 & 2,868 & 3,543 & 4,406 & 5,909 & 11,297 \\
\hline 2005 & 2,727 & 224 & 463 & 696 & 975 & 1,494 & 2,143 & 2,861 & 3,567 & 4,421 & 5,821 & 11,556 \\
\hline 2006 & 2,698 & 214 & 464 & 633 & 958 & 1,441 & 2,134 & 2,884 & 3,526 & 4,432 & 5,813 & 11,771 \\
\hline 2007 & 2,623 & 182 & 426 & 591 & 901 & 1,421 & 2,146 & 2,841 & 3,529 & 4,399 & 5,682 & 11,766 \\
\hline 2008 & 2,542 & 195 & 431 & 574 & 910 & 1,410 & 2,160 & 2,827 & 3,570 & 4,374 & 5,460 & 11,672 \\
\hline 2009 & 2,493 & 161 & 405 & 591 & 904 & 1,374 & 2,055 & 2,787 & 3,460 & 4,228 & 5,352 & 10,917 \\
\hline 2010 & 2,488 & 160 & 434 & 571 & 897 & 1,409 & 2,097 & 2,777 & 3,457 & 4,272 & 5,410 & 11,185 \\
\hline
\end{tabular}

Source: Authors' tabulations of the 1996, 2001, 2004, 2008 SIPP data matched to the Social Security Administration's Detailed Earnings Record (DER).

Note: Contributions are based on positive deferred contributions on the DER from 1990 to 2010. 
Table 4. Change in Median Contribution Amount for Wage and Salary Participants Ages 20 to 69, by Year and Own Earnings (percent)

\begin{tabular}{|c|c|c|c|c|c|c|c|c|c|c|c|c|}
\hline \multirow[b]{2}{*}{ Year } & \multicolumn{12}{|c|}{ Own Earnings (thousands of 2011 dollars) } \\
\hline & All & $0-10$ & $10-15$ & $15-20$ & $20-30$ & $30-40$ & $40-50$ & $50-60$ & $60-70$ & $70-80$ & $80-100$ & $100+$ \\
\hline 1991 & -0.1 & -26.6 & -6.1 & 12.3 & 7.3 & 6.0 & -1.2 & -1.8 & 1.8 & 2.1 & 1.4 & 3.2 \\
\hline 1992 & -1.9 & -17.6 & 4.4 & -18.3 & -5.5 & -4.6 & -0.5 & 1.6 & -1.3 & -1.0 & 1.2 & 1.7 \\
\hline 1993 & 3.9 & 8.3 & -0.8 & 3.5 & 1.1 & 4.2 & 5.3 & 3.3 & 3.3 & 3.5 & 1.1 & 2.0 \\
\hline 1994 & 1.1 & 1.4 & 5.9 & 4.3 & 4.7 & 2.7 & -1.9 & 3.1 & 1.6 & -0.9 & 3.9 & 2.6 \\
\hline 1995 & 1.4 & -10.5 & -6.1 & -4.2 & -3.9 & -0.5 & 2.0 & 3.2 & 1.3 & 3.8 & 2.7 & 0.5 \\
\hline 1996 & 2.8 & 13.6 & 5.2 & 9.2 & 0.5 & 2.6 & 2.5 & 0.9 & 5.2 & 2.9 & 0.1 & 6.7 \\
\hline 1997 & 3.2 & -17.8 & -9.7 & -3.2 & 4.0 & -0.2 & 0.7 & 1.2 & 4.1 & 1.1 & 3.2 & 4.2 \\
\hline 1998 & 4.1 & 27.6 & 12.8 & 0.9 & -0.3 & 0.9 & 1.8 & 0.6 & -2.9 & 4.4 & 3.0 & 4.8 \\
\hline 1999 & 1.1 & -14.8 & -11.1 & -2.5 & -1.2 & 1.2 & 0.4 & 1.4 & -0.6 & 1.2 & -0.2 & 1.9 \\
\hline 2000 & 0.1 & 7.8 & -0.3 & -1.2 & -1.9 & -0.3 & -1.8 & 1.0 & 2.8 & -1.1 & 3.1 & 1.4 \\
\hline 2001 & 1.7 & 1.8 & 2.5 & 2.6 & 4.1 & -0.6 & 3.4 & 3.1 & 0.9 & 0.9 & 0.2 & 1.3 \\
\hline 2002 & 0.0 & -4.5 & -2.1 & -2.4 & -4.3 & 0.2 & -1.4 & -0.6 & 1.9 & 0.6 & 3.7 & 3.5 \\
\hline 2003 & 1.7 & 5.2 & 13.2 & 5.1 & 4.4 & -1.5 & 0.5 & -1.5 & -6.2 & -2.0 & -1.8 & 2.9 \\
\hline 2004 & 2.0 & -6.0 & -9.0 & -8.1 & -3.7 & -2.7 & -0.1 & 0.5 & 1.2 & -0.7 & -0.1 & 3.1 \\
\hline 2005 & -0.9 & 10.0 & -9.0 & 5.4 & 1.7 & 1.4 & -0.3 & -0.2 & 0.7 & 0.3 & -1.5 & 2.3 \\
\hline 2006 & -1.1 & -4.5 & 0.2 & -9.1 & -1.7 & -3.5 & -0.4 & 0.8 & -1.1 & 0.3 & -0.1 & 1.9 \\
\hline 2007 & -2.8 & -15.1 & -8.1 & -6.6 & -6.0 & -1.4 & 0.6 & -1.5 & 0.1 & -0.7 & -2.2 & -0.1 \\
\hline 2008 & -3.1 & 7.4 & 1.0 & -2.9 & 1.1 & -0.8 & 0.7 & -0.5 & 1.1 & -0.6 & -3.9 & -0.8 \\
\hline 2009 & -2.0 & -17.5 & -5.9 & 3.0 & -0.7 & -2.6 & -4.9 & -1.4 & -3.1 & -3.3 & -2.0 & -6.5 \\
\hline 2010 & -0.2 & -0.8 & 7.3 & -3.4 & -0.8 & 2.5 & 2.1 & -0.4 & -0.1 & 1.0 & 1.1 & 2.5 \\
\hline 2007-09 & -4.9 & -11.4 & -5.0 & 0.0 & 0.4 & -3.3 & -4.2 & -1.9 & -2.0 & -3.9 & -5.8 & -7.2 \\
\hline 2007-10 & -5.1 & -12.1 & 1.9 & -3.4 & -0.4 & -0.9 & -2.3 & -2.3 & -2.1 & -2.9 & -4.8 & -4.9 \\
\hline
\end{tabular}

Source: Authors' tabulations of the 1996, 2001, 2004, 2008 SIPP data matched to the Social Security Administration's Detailed Earnings Record (DER).

Note: Contributions are based on positive deferred contributions on the DER from 1990 to 2010. 
Table 5. Median Contribution Rate for Wage and Salary Participants Ages 20 to 69, by Year and Age (percent)

\begin{tabular}{llllllll}
\hline & \multicolumn{5}{c}{ Age } \\
\cline { 2 - 7 } Year & All & $\mathbf{2 0 - 2 9}$ & $\mathbf{3 0 - 3 9}$ & $\mathbf{4 0 - 4 9}$ & $\mathbf{5 0 - 5 9}$ & $\mathbf{6 0 - 6 4}$ & $\mathbf{6 5 - 6 9}$ \\
\hline $\mathbf{1 9 9 0}$ & 4.7 & 3.4 & 4.1 & 4.9 & 5.9 & 6.9 & 7.0 \\
$\mathbf{1 9 9 1}$ & 4.7 & 3.7 & 4.1 & 4.9 & 6.0 & 6.7 & 6.3 \\
$\mathbf{1 9 9 2}$ & 4.7 & 3.4 & 4.1 & 4.8 & 5.9 & 6.9 & 6.3 \\
$\mathbf{1 9 9 3}$ & 4.8 & 3.6 & 4.2 & 5.0 & 6.0 & 6.7 & 6.3 \\
$\mathbf{1 9 9 4}$ & 4.9 & 3.7 & 4.4 & 5.0 & 6.0 & 6.5 & 7.0 \\
$\mathbf{1 9 9 5}$ & 4.9 & 3.6 & 4.5 & 5.0 & 6.0 & 6.3 & 6.4 \\
$\mathbf{1 9 9 6}$ & 5.0 & 3.8 & 4.7 & 5.0 & 6.0 & 6.6 & 6.5 \\
$\mathbf{1 9 9 7}$ & 5.0 & 3.7 & 4.7 & 5.0 & 6.0 & 6.6 & 6.6 \\
$\mathbf{1 9 9 8}$ & 5.0 & 3.9 & 4.9 & 5.1 & 6.0 & 6.9 & 6.6 \\
$\mathbf{1 9 9 9}$ & 5.1 & 3.9 & 4.9 & 5.1 & 6.0 & 6.8 & 6.6 \\
$\mathbf{2 0 0 0}$ & 5.1 & 3.8 & 4.9 & 5.1 & 6.0 & 6.6 & 6.5 \\
$\mathbf{2 0 0 1}$ & 5.2 & 3.9 & 5.0 & 5.2 & 6.0 & 6.9 & 7.1 \\
$\mathbf{2 0 0 2}$ & 5.2 & 3.8 & 5.0 & 5.3 & 6.1 & 6.7 & 7.0 \\
$\mathbf{2 0 0 3}$ & 5.2 & 3.8 & 4.9 & 5.2 & 6.1 & 6.6 & 7.2 \\
$\mathbf{2 0 0 4}$ & 5.2 & 3.5 & 4.9 & 5.3 & 6.1 & 6.8 & 7.5 \\
$\mathbf{2 0 0 5}$ & 5.2 & 3.6 & 4.9 & 5.2 & 6.1 & 7.1 & 7.2 \\
$\mathbf{2 0 0 6}$ & 5.2 & 3.5 & 4.8 & 5.3 & 6.1 & 6.8 & 7.1 \\
$\mathbf{2 0 0 7}$ & 5.1 & 3.3 & 4.7 & 5.2 & 6.1 & 6.7 & 7.0 \\
$\mathbf{2 0 0 8}$ & 5.1 & 3.3 & 4.6 & 5.1 & 6.0 & 6.5 & 6.9 \\
$\mathbf{2 0 0 9}$ & 5.0 & 3.2 & 4.4 & 5.0 & 5.8 & 6.2 & 6.5 \\
$\mathbf{2 0 1 0}$ & 5.0 & 3.1 & 4.5 & 5.1 & 5.9 & 6.3 & 6.4 \\
\hline & & & & & & & \\
\hline
\end{tabular}

Source: Authors' tabulations of the 1996, 2001, 2004, 2008 SIPP data matched to the Social Security Administration's Detailed Earnings Record (DER).

Note: Contributions are based on positive deferred contributions on the DER from 1990 to 2010. 
Table 6. Median Contribution Rate for Wage and Salary Participants Ages 20 to 69, by Year and Own Earnings (percent)

\begin{tabular}{|c|c|c|c|c|c|c|c|c|c|c|c|c|}
\hline \multirow[b]{2}{*}{ Year } & \multicolumn{12}{|c|}{ Own Earnings (thousands of 2011 dollars) } \\
\hline & All & $0-10$ & $10-15$ & $15-20$ & $20-30$ & $30-40$ & $40-50$ & $50-60$ & $60-70$ & $70-80$ & $80-100$ & $100+$ \\
\hline 1990 & 4.7 & 5.8 & 4.1 & 4.0 & 3.7 & 4.0 & 4.3 & 4.5 & 4.9 & 5.0 & 5.4 & 5.3 \\
\hline 1991 & 4.7 & 4.3 & 4.0 & 4.5 & 3.9 & 4.1 & 4.2 & 4.4 & 5.0 & 5.1 & 5.4 & 5.5 \\
\hline 1992 & 4.7 & 4.0 & 4.0 & 3.8 & 3.8 & 4.0 & 4.3 & 4.5 & 4.9 & 5.1 & 5.6 & 5.5 \\
\hline 1993 & 4.8 & 4.0 & 4.1 & 3.7 & 3.8 & 4.1 & 4.5 & 4.7 & 5.0 & 5.3 & 5.7 & 5.7 \\
\hline 1994 & 4.9 & 4.5 & 4.3 & 4.0 & 4.0 & 4.2 & 4.5 & 4.9 & 5.0 & 5.3 & 5.9 & 5.6 \\
\hline 1995 & 4.9 & 4.0 & 4.0 & 3.8 & 3.8 & 4.1 & 4.6 & 5.0 & 5.1 & 5.5 & 6.0 & 5.5 \\
\hline 1996 & 5.0 & 4.4 & 4.2 & 4.0 & 3.9 & 4.3 & 4.7 & 5.0 & 5.5 & 5.6 & 6.0 & 5.8 \\
\hline 1997 & 5.0 & 3.8 & 4.0 & 3.9 & 4.0 & 4.3 & 4.8 & 5.0 & 5.7 & 5.8 & 6.1 & 5.9 \\
\hline 1998 & 5.0 & 4.8 & 4.4 & 4.0 & 4.0 & 4.3 & 4.8 & 5.0 & 5.5 & 6.0 & 6.2 & 6.0 \\
\hline 1999 & 5.1 & 4.2 & 4.1 & 3.9 & 3.9 & 4.4 & 4.9 & 5.1 & 5.5 & 6.1 & 6.2 & 6.0 \\
\hline 2000 & 5.1 & 4.5 & 4.0 & 3.8 & 3.9 & 4.3 & 4.8 & 5.1 & 5.6 & 6.0 & 6.4 & 6.0 \\
\hline 2001 & 5.2 & 4.4 & 4.0 & 4.0 & 4.0 & 4.4 & 5.0 & 5.2 & 5.7 & 6.0 & 6.4 & 6.1 \\
\hline 2002 & 5.2 & 4.6 & 3.9 & 4.0 & 3.9 & 4.4 & 4.9 & 5.2 & 5.8 & 6.1 & 6.7 & 6.5 \\
\hline 2003 & 5.2 & 4.5 & 4.5 & 4.1 & 4.0 & 4.3 & 4.9 & 5.1 & 5.4 & 6.0 & 6.6 & 6.5 \\
\hline 2004 & 5.2 & 4.7 & 4.1 & 3.7 & 3.9 & 4.2 & 4.9 & 5.2 & 5.4 & 6.0 & 6.6 & 6.8 \\
\hline 2005 & 5.2 & 4.7 & 3.6 & 4.0 & 3.9 & 4.2 & 4.9 & 5.2 & 5.5 & 6.0 & 6.4 & 6.8 \\
\hline 2006 & 5.2 & 4.2 & 3.6 & 3.6 & 3.8 & 4.1 & 4.9 & 5.2 & 5.5 & 6.0 & 6.4 & 7.0 \\
\hline 2007 & 5.1 & 4.0 & 3.3 & 3.2 & 3.6 & 4.1 & 4.9 & 5.1 & 5.4 & 5.9 & 6.3 & 6.9 \\
\hline 2008 & 5.1 & 4.0 & 3.4 & 3.2 & 3.6 & 4.1 & 4.9 & 5.1 & 5.5 & 5.9 & 6.2 & 7.0 \\
\hline 2009 & 5.0 & 3.4 & 3.2 & 3.3 & 3.6 & 4.0 & 4.6 & 5.1 & 5.3 & 5.7 & 6.0 & 6.8 \\
\hline 2010 & 5.0 & 3.6 & 3.4 & 3.2 & 3.6 & 4.1 & 4.8 & 5.1 & 5.3 & 5.8 & 6.1 & 6.7 \\
\hline
\end{tabular}

Source: Authors' tabulations of the 1996, 2001, 2004, 2008 SIPP data matched to the Social Security Administration's Detailed Earnings Record (DER).

Note: Contributions are based on positive deferred contributions on the DER from 1990 to 2010. 
Table 7. Logistic Regression of the Likelihood of Wage and Salary Workers Ages 20 to 69 Participating in 401(k) Plans, 1991 to 2010

\begin{tabular}{|c|c|c|c|c|c|c|}
\hline & \multicolumn{3}{|c|}{ Model 1} & \multicolumn{3}{|c|}{ Model 2} \\
\hline & $\begin{array}{r}\text { Parameter } \\
\text { Estimate }\end{array}$ & $\begin{array}{r}\text { Standard } \\
\text { Error }\end{array}$ & & $\begin{array}{r}\text { Parameter } \\
\text { Estimate }\end{array}$ & $\begin{array}{r}\text { Standard } \\
\text { Error }\end{array}$ & \\
\hline Intercept & -14.696 & 0.031 & $\star *$ & -14.036 & 0.027 & ** \\
\hline Log earnings (\$2011) & 1.199 & 0.002 & ** & 1.189 & 0.002 & ** \\
\hline $\begin{array}{l}\text { Gets a job this year after } \\
\text { unemployment }\end{array}$ & -0.728 & 0.020 & ** & -0.732 & 0.020 & ** \\
\hline Change jobs this year & -0.440 & 0.004 & ** & -0.435 & 0.004 & ** \\
\hline Change jobs last year & -0.422 & 0.004 & $\star \star$ & -0.419 & 0.004 & ** \\
\hline $\begin{array}{l}\text { Number of work years since } \\
\text { age } 20\end{array}$ & 0.021 & 0.000 & $\star \star$ & 0.021 & 0.000 & ** \\
\hline Age & 0.056 & 0.001 & ** & & & \\
\hline Age Squared & -0.001 & 0.000 & ** & & & \\
\hline Age Spline 20-29 & & & & 0.062 & 0.001 & ** \\
\hline Age Spline 30-39 & & & & -0.085 & 0.001 & ** \\
\hline Age Spline 40-49 & & & & 0.012 & 0.001 & ** \\
\hline Age Spline 50-59 & & & & -0.007 & 0.001 & ** \\
\hline Age Spline 60-69 & & & & -0.038 & 0.002 & ** \\
\hline Year 1992 & 0.066 & 0.011 & ** & 0.067 & 0.011 & ** \\
\hline Year 1993 & 0.165 & 0.011 & $\star *$ & 0.166 & 0.011 & $\star *$ \\
\hline Year 1994 & 0.280 & 0.011 & $\star \star$ & 0.282 & 0.011 & $\star *$ \\
\hline Year 1995 & 0.371 & 0.011 & $\star *$ & 0.374 & 0.011 & ** \\
\hline Year 1996 & 0.466 & 0.011 & $* *$ & 0.470 & 0.011 & ** \\
\hline Year 1997 & 0.547 & 0.011 & $\star *$ & 0.551 & 0.011 & ** \\
\hline Year 1998 & 0.614 & 0.011 & ** & 0.619 & 0.011 & $\star \star$ \\
\hline Year 1999 & 0.657 & 0.010 & $\star *$ & 0.663 & 0.010 & ** \\
\hline Year 2000 & 0.711 & 0.010 & $* *$ & 0.718 & 0.010 & ** \\
\hline Year 2001 & 0.727 & 0.010 & $\star *$ & 0.735 & 0.010 & ** \\
\hline Year 2002 & 0.679 & 0.010 & $\star *$ & 0.686 & 0.010 & $\star *$ \\
\hline Year 2003 & 0.642 & 0.010 & $* *$ & 0.650 & 0.010 & ** \\
\hline Year 2004 & 0.645 & 0.010 & $\star *$ & 0.652 & 0.010 & ** \\
\hline Year 2005 & 0.682 & 0.010 & $\star *$ & 0.690 & 0.010 & ** \\
\hline Year 2006 & 0.725 & 0.010 & $\star *$ & 0.732 & 0.010 & ** \\
\hline Year 2007 & 0.775 & 0.010 & ** & 0.781 & 0.010 & ** \\
\hline Year 2008 & 0.821 & 0.010 & $\star \star$ & 0.827 & 0.010 & ** \\
\hline Year 2009 & 0.772 & 0.010 & $\star *$ & 0.778 & 0.010 & ** \\
\hline Year 2010 & 0.742 & 0.011 & $\star *$ & 0.746 & 0.011 & ** \\
\hline SIPP 2001 & 0.011 & 0.005 & & 0.010 & 0.005 & \\
\hline SIPP 2004 & 0.026 & 0.004 & $\star *$ & 0.025 & 0.004 & ** \\
\hline SIPP 2008 & -0.012 & 0.004 & & -0.014 & 0.004 & \\
\hline N (person-years) & 2406035 & & & 2406035 & & \\
\hline -2 Log Likelihood & 2473126 & & & 2470566 & & \\
\hline
\end{tabular}

Source: Authors' tabulations of the 1996, 2001, 2004, 2008 SIPP data matched to the Social Security Administration's Detailed Earnings Record (DER).

Note: Table includes all workers in all years 1991-2010. ** indicates $p<0.001,{ }^{*}$ indicates $p<0.01$ 
Table 8. Logistic Regression Estimates of Whether a Wage and Salary Worker Offered a DC Plan Contributes to Their Plan (1996, 2001, 2004, 2008 SIPP)

\begin{tabular}{|c|c|c|c|c|c|c|}
\hline & \multicolumn{3}{|c|}{ Model 1} & \multicolumn{3}{|c|}{ Model 2} \\
\hline & $\begin{array}{l}\text { Parameter } \\
\text { Estimate }\end{array}$ & $\begin{array}{l}\text { Standard } \\
\text { Error }\end{array}$ & & $\begin{array}{l}\text { Parameter } \\
\text { Estimate }\end{array}$ & $\begin{array}{l}\text { Standard } \\
\text { Error }\end{array}$ & \\
\hline Intercept & -9.310 & 0.068 & $\star *$ & -9.206 & 0.060 & ** \\
\hline Married & -0.059 & 0.009 & ** & -0.068 & 0.009 & ** \\
\hline Two earners & -0.540 & 0.009 & ** & -0.534 & 0.009 & ** \\
\hline Number of dependents & -0.055 & 0.003 & ** & -0.059 & 0.004 & ** \\
\hline Have a baby this year & 0.146 & 0.018 & ** & 0.119 & 0.018 & ** \\
\hline Have a baby last year & 0.082 & 0.017 & ** & 0.055 & 0.017 & \\
\hline Purchase a home this year & -0.041 & 0.017 & & -0.052 & 0.017 & \\
\hline Purchase a home last year & -0.027 & 0.016 & & -0.039 & 0.016 & \\
\hline Own a home & 0.176 & 0.007 & ** & 0.180 & 0.007 & ** \\
\hline Become work limited this year & 0.373 & 0.066 & $* *$ & 0.371 & 0.066 & ** \\
\hline Become work limited last year & 0.223 & 0.064 & * & 0.221 & 0.064 & * \\
\hline Log of total earnings & 0.789 & 0.005 & ** & 0.782 & 0.005 & ** \\
\hline Become divorced this year & -0.122 & 0.029 & ** & -0.134 & 0.029 & ** \\
\hline Become widowed this year & -0.016 & 0.074 & & -0.027 & 0.074 & \\
\hline Get married this year & 0.011 & 0.019 & & 0.013 & 0.020 & \\
\hline Spouse contributes to a DC plan & 0.219 & 0.011 & ** & 0.219 & 0.011 & ** \\
\hline $\begin{array}{l}\text { Spouse's contribution rate } \\
\text { (contribution/earnings) }\end{array}$ & 1.786 & 0.114 & $\star *$ & 1.798 & 0.114 & $\star *$ \\
\hline Employer contributes to plan & -0.047 & 0.007 & ** & -0.046 & 0.007 & ** \\
\hline Have a DB plan & 0.344 & 0.007 & ** & 0.347 & 0.007 & ** \\
\hline Have a CB plan & 0.213 & 0.015 & ** & 0.213 & 0.015 & ** \\
\hline Currently work limited & -0.171 & 0.022 & ** & -0.176 & 0.022 & ** \\
\hline $\begin{array}{l}\text { Spouse currently work limited } \\
\text { Gets a job this year after }\end{array}$ & -0.025 & 0.018 & & -0.023 & 0.018 & \\
\hline unemployment & -1.102 & 0.041 & ** & -1.103 & 0.041 & ** \\
\hline $\begin{array}{l}\text { Spouse gets a job this year after } \\
\text { unemployment }\end{array}$ & 0.267 & 0.026 & ** & 0.264 & 0.026 & $\star *$ \\
\hline Change jobs this year & -0.331 & 0.008 & ** & -0.326 & 0.008 & ** \\
\hline Spouse changes jobs this year & 0.062 & 0.008 & ** & 0.062 & 0.008 & ** \\
\hline Change jobs last year & -0.374 & 0.008 & ** & -0.371 & 0.008 & ** \\
\hline Spouse changes jobs last year & 0.041 & 0.009 & ** & 0.040 & 0.009 & ** \\
\hline Spouses loses a job this year & -0.040 & 0.024 & & -0.041 & 0.024 & \\
\hline $\begin{array}{l}\text { Spouse begins to contribute to } \\
\text { DC plan this year }\end{array}$ & -0.059 & 0.022 & & -0.061 & 0.022 & \\
\hline $\begin{array}{l}\text { Can borrow from pension plan } \\
\text { Number of work years since age }\end{array}$ & 0.480 & 0.007 & $\star *$ & 0.478 & 0.007 & ** \\
\hline 20 & 0.019 & 0.001 & ** & 0.019 & 0.001 & ** \\
\hline Age & 0.020 & 0.002 & ** & & & \\
\hline Age squared & 0.000 & 0.000 & $* *$ & & & \\
\hline Age Spline 20-29 & & & & 0.041 & 0.002 & ** \\
\hline Age Spline 30-39 & & & & -0.058 & 0.003 & ** \\
\hline Age Spline 40-49 & & & & 0.007 & 0.002 & \\
\hline Age Spline 50-59 & & & & 0.010 & 0.003 & ** \\
\hline Age Spline 60-69 & & & & -0.037 & 0.005 & ** \\
\hline
\end{tabular}


Table 8. Logistic Regression Estimates of Whether a Wage and Salary Worker Offered a DC Plan Contributes to Their Plan (1996, 2001, 2004, 2008 SIPP)

\begin{tabular}{|c|c|c|c|c|c|c|}
\hline & \multicolumn{3}{|c|}{ Model 1} & \multicolumn{3}{|c|}{ Model 2} \\
\hline & $\begin{array}{l}\text { Parameter } \\
\text { Estimate }\end{array}$ & $\begin{array}{c}\text { Standard } \\
\text { Error }\end{array}$ & & $\begin{array}{l}\text { Parameter } \\
\text { Estimate }\end{array}$ & $\begin{array}{c}\text { Standard } \\
\text { Error }\end{array}$ & \\
\hline Year 1992 & 0.086 & 0.022 & $\star \star *$ & 0.088 & 0.022 & ** \\
\hline Year 1993 & 0.176 & 0.022 & ** & 0.178 & 0.022 & $\star \star$ \\
\hline Year 1994 & 0.299 & 0.021 & $\star \star$ & 0.302 & 0.021 & ** \\
\hline Year 1995 & 0.422 & 0.021 & $\star *$ & 0.426 & 0.021 & $* *$ \\
\hline Year 1996 & 0.518 & 0.020 & ** & 0.522 & 0.020 & ** \\
\hline Year 1997 & 0.664 & 0.020 & ** & 0.669 & 0.020 & $\star \star$ \\
\hline Year 1998 & 0.791 & 0.020 & $* *$ & 0.796 & 0.020 & ** \\
\hline Year 1999 & 0.804 & 0.022 & $* *$ & 0.810 & 0.022 & ** \\
\hline Year 2000 & 0.882 & 0.021 & ** & 0.888 & 0.021 & ** \\
\hline Year 2001 & 0.910 & 0.021 & ** & 0.915 & 0.021 & $\star *$ \\
\hline Year 2002 & 0.869 & 0.020 & ** & 0.873 & 0.020 & $\star *$ \\
\hline Year 2003 & 0.851 & 0.020 & ** & 0.854 & 0.020 & ** \\
\hline Year 2004 & 0.841 & 0.021 & ** & 0.845 & 0.021 & $\star *$ \\
\hline Year 2005 & 0.909 & 0.021 & $* *$ & 0.912 & 0.021 & ** \\
\hline Year 2006 & 1.002 & 0.020 & $* *$ & 1.003 & 0.021 & ** \\
\hline Year 2007 & 1.029 & 0.023 & ** & 1.031 & 0.023 & ** \\
\hline Year 2008 & 1.121 & 0.023 & $\star *$ & 1.122 & 0.023 & $\star \star$ \\
\hline Year 2009 & 1.031 & 0.023 & $\star \star$ & 1.029 & 0.023 & $\star *$ \\
\hline SIPP 2001 & -0.194 & 0.012 & $* *$ & -0.193 & 0.012 & ** \\
\hline SIPP 2004 & -0.216 & 0.011 & $\star *$ & -0.214 & 0.011 & $\star *$ \\
\hline SIPP 2008 & -0.328 & 0.011 & $\star *$ & -0.325 & 0.011 & $\star *$ \\
\hline N (person-years) & 564,259 & & & 564,259 & & \\
\hline -2 log likelihood & 662,993 & & & 662,585 & & \\
\hline
\end{tabular}

Source: Authors' tabulations of the 1996, 2001, 2004, 2008 SIPP data matched to the Social Security Administration's Detailed Earnings Record (DER).

Note: Table includes all workers from 1991 to 2009 over the duration of the SIPP interview pension job. ** indicates $p<0.001,{ }^{*}$ indicates $p<0.01$ 
Table 9. OLS Regression Estimates of Contribution Amount Among Wage and Salary Participants Ages 20 to 69,1991 to 2010

\begin{tabular}{|c|c|c|c|c|c|c|}
\hline & \multicolumn{3}{|c|}{ Model 1} & \multicolumn{3}{|c|}{ Model 2} \\
\hline & $\begin{array}{r}\text { Parameter } \\
\text { Estimate }\end{array}$ & $\begin{array}{r}\text { Standard } \\
\text { Error }\end{array}$ & & $\begin{array}{r}\text { Parameter } \\
\text { Estimate }\end{array}$ & $\begin{array}{r}\text { Standar } \\
\text { d Error }\end{array}$ & \\
\hline Intercept & -35574.00 & 79.694 & ** & -36765.00 & 65.646 & ** \\
\hline Log earnings (\$2011) & 3778.09 & 5.671 & ** & 3786.65 & 5.682 & ** \\
\hline $\begin{array}{l}\text { Gets a job this year aft } \\
\text { unemployment }\end{array}$ & 3315.92 & 64.965 & ** & 3302.55 & 64.934 & ** \\
\hline Change jobs this year & -519.54 & 10.008 & ** & -530.51 & 10.011 & ** \\
\hline Change jobs last year & -226.59 & 11.397 & $\star *$ & -234.82 & 11.396 & ** \\
\hline Number of work years & & & & & & \\
\hline 20 & -28.18 & 0.996 & ** & -29.61 & 0.999 & ** \\
\hline Age & -127.51 & 2.776 & ** & & & \\
\hline Age Squared & 2.37 & 0.031 & & & & \\
\hline Age Spline 20-29 & & & & -85.33 & 3.136 & \\
\hline Age Spline 30-39 & & & & 157.52 & 4.197 & ** \\
\hline Age Spline 40-49 & & & & 4.32 & 2.841 & \\
\hline Age Spline 50-59 & & & & 70.85 & 3.066 & ** \\
\hline Age Spline 60-69 & & & & -41.23 & 6.148 & ** \\
\hline Year 1992 & -131.56 & 30.909 & & -129.10 & 30.893 & ** \\
\hline Year 1993 & 32.12 & 30.382 & & 34.58 & 30.367 & \\
\hline Year 1994 & 41.71 & 29.775 & & 43.75 & 29.760 & \\
\hline Year 1995 & 8.64 & 29.317 & & 9.49 & 29.303 & \\
\hline Year 1996 & 97.99 & 28.885 & * & 97.97 & 28.871 & * \\
\hline Year 1997 & 121.24 & 28.450 & $\star *$ & 120.55 & 28.435 & ** \\
\hline Year 1998 & 263.41 & 28.059 & ** & 261.99 & 28.046 & ** \\
\hline Year 1999 & 227.99 & 27.832 & $\star *$ & 225.40 & 27.818 & ** \\
\hline Year 2000 & 214.20 & 27.617 & ** & 211.48 & 27.603 & ** \\
\hline Year 2001 & 264.72 & 27.520 & $\star *$ & 260.95 & 27.507 & ** \\
\hline Year 2002 & 383.79 & 27.598 & $\star *$ & 379.09 & 27.585 & ** \\
\hline Year 2003 & 418.14 & 27.671 & ** & 413.96 & 27.657 & ** \\
\hline Year 2004 & 537.60 & 27.626 & $\star *$ & 533.28 & 27.613 & ** \\
\hline Year 2005 & 645.29 & 27.543 & $\star *$ & 640.33 & 27.530 & ** \\
\hline Year 2006 & 700.78 & 27.408 & ** & 695.57 & 27.396 & ** \\
\hline Year 2007 & 700.49 & 27.269 & ** & 695.71 & 27.256 & ** \\
\hline Year 2008 & 592.37 & 27.223 & $\star *$ & 587.55 & 27.210 & ** \\
\hline Year 2009 & 554.62 & 27.425 & ** & 551.66 & 27.411 & ** \\
\hline Year 2010 & 556.56 & 27.579 & $\star *$ & 554.59 & 27.565 & ** \\
\hline SIPP 2001 & 9.06 & 12.420 & & 10.00 & 12.414 & \\
\hline SIPP 2004 & 47.94 & 10.453 & ** & 48.64 & 10.448 & ** \\
\hline SIPP 2008 & 63.54 & 10.352 & $\star *$ & 64.71 & 10.348 & ** \\
\hline N (person-years) & 878,618 & & & 878,618 & & \\
\hline R-Squared & 0.3864 & & & 0.3871 & & \\
\hline
\end{tabular}

Source: Authors' tabulations of the 1996, 2001, 2004, 2008 SIPP data matched to the Social Security Administration's Detailed Earnings Record (DER).

Note: Table includes all workers in all years 1991-2010. ** indicates $p<0.001$, * indicates $p<0.01$ 
Table 10. OLS Regression Estimates of Contribution Amount Among Wage and Salary Participants Ages 20 to 69,1991 to 2009

\begin{tabular}{|c|c|c|c|c|c|c|}
\hline & \multicolumn{3}{|c|}{ Model 1} & \multicolumn{3}{|c|}{ Model 2} \\
\hline & $\begin{array}{l}\text { Parameter } \\
\text { Estimate }\end{array}$ & $\begin{array}{r}\text { Standar } \\
\text { d Error }\end{array}$ & & $\begin{array}{l}\text { Parameter } \\
\text { Estimate }\end{array}$ & $\begin{array}{r}\text { Standard } \\
\text { Error }\end{array}$ & \\
\hline Intercept & -34304.00 & 101.653 & $\star \star$ & -36735.0 & 86.418 & ** \\
\hline Married & 123.01 & 12.493 & $\star \star$ & 138.9 & 12.509 & ** \\
\hline Two earners & -2080.87 & 13.084 & $\star *$ & -2092.6 & 13.105 & ** \\
\hline Number of dependents & -42.49 & 5.533 & $\star *$ & -40.8 & 5.665 & ** \\
\hline Have a baby this year & 230.57 & 25.949 & ** & 282.3 & 26.056 & $\star \star$ \\
\hline Have a baby last year & 135.49 & 25.271 & $\star \star$ & 183.8 & 25.362 & $\star \star$ \\
\hline Purchase a home this year & -191.61 & 24.895 & ** & -172.1 & 24.899 & $\star \star$ \\
\hline Purchase a home last year & -129.09 & 24.351 & $\star *$ & -109.0 & 24.358 & ** \\
\hline Own a home & 103.40 & 10.577 & $\star *$ & 96.7 & 10.576 & ** \\
\hline Become work limited this year & 235.03 & 86.001 & & 234.3 & 85.961 & \\
\hline Become work limited last year & 319.90 & 98.275 & & 320.7 & 98.228 & \\
\hline Log of total earnings & 3753.34 & 7.774 & $\star \star$ & 3762.7 & 7.788 & ** \\
\hline Become divorced this year & -354.44 & 43.666 & ** & -329.9 & 43.659 & ** \\
\hline Become widowed this year & -169.11 & 111.405 & & -148.0 & 111.356 & \\
\hline Get married this year & -57.46 & 29.164 & & -59.2 & 29.151 & \\
\hline Spouse contributes to a DC plan & -1625.09 & 15.601 & ** & -1619.2 & 15.597 & ** \\
\hline $\begin{array}{l}\text { Spouse's contribution rate } \\
\text { (contribution/earnings) }\end{array}$ & 17025.00 & 130.428 & ** & 16981.0 & 130.383 & ** \\
\hline Employer contributes to plan & 6.00 & 11.479 & & 7.6 & 11.474 & \\
\hline Have a DB plan & 26.02 & 10.043 & & 22.5 & 10.042 & \\
\hline Have a CB plan & 148.17 & 22.015 & ** & 148.1 & 22.005 & ** \\
\hline Currently work limited & -223.94 & 37.569 & $\star \star$ & -224.2 & 37.555 & ** \\
\hline Spouse currently work limited & -275.22 & 29.526 & ** & -283.3 & 29.519 & ** \\
\hline $\begin{array}{l}\text { Gets a job this year after } \\
\text { unemployment }\end{array}$ & 1449.76 & 75.328 & ** & 1432.1 & 75.296 & ** \\
\hline $\begin{array}{l}\text { Spouse gets a job this year after } \\
\text { unemployment }\end{array}$ & 1285.17 & 39.477 & $\star \star$ & 1290.2 & 39.459 & ** \\
\hline Change jobs this year & -535.53 & 11.605 & $\star \star$ & -545.0 & 11.608 & $\star *$ \\
\hline Spouse changes jobs this year & 189.56 & 11.932 & $\star *$ & 189.9 & 11.926 & ** \\
\hline Change jobs last year & -233.77 & 13.207 & $\star \star$ & -241.2 & 13.205 & $\star \star$ \\
\hline Spouse changes jobs last year & 120.58 & 13.587 & ** & 123.1 & 13.581 & ** \\
\hline $\begin{array}{l}\text { Spouses loses a job this year } \\
\text { Spouse begins to contribute to }\end{array}$ & 66.49 & 35.060 & & 64.1 & 35.045 & \\
\hline DC plan this year & 257.24 & 30.450 & $\star *$ & 260.2 & 30.436 & $\star *$ \\
\hline $\begin{array}{l}\text { Can borrow from pension plan } \\
\text { Number of work years since age }\end{array}$ & 191.26 & 11.681 & ** & 192.8 & 11.677 & $\star \star$ \\
\hline 20 & 19.53 & 1.127 & ** & 17.8 & 1.130 & ** \\
\hline Age & -192.90 & 3.484 & $\star \star$ & & & \\
\hline Age squared & 2.63 & 0.039 & ** & & & \\
\hline Age Spline 20-29 & & & & -137.0 & 3.704 & ** \\
\hline Age Spline 30-39 & & & & 164.4 & 4.901 & $\star \star$ \\
\hline Age Spline 40-49 & & & & 4.4 & 3.351 & \\
\hline Age Spline 50-59 & & & & 77.9 & 3.661 & ** \\
\hline Age Spline 60-69 & & & & -21.2 & 7.589 & \\
\hline
\end{tabular}




\begin{tabular}{|c|c|c|c|c|c|c|}
\hline Year 1992 & -144.16 & 29.609 & $* *$ & -141.67 & 29.595 & ** \\
\hline Year 1993 & 0.68 & 29.109 & & 3.03 & 29.096 & \\
\hline Year 1994 & -2.10 & 28.539 & & -0.16 & 28.526 & \\
\hline Year 1995 & -35.57 & 28.117 & & -34.63 & 28.104 & \\
\hline Year 1996 & 50.83 & 27.723 & & 51.23 & 27.710 & \\
\hline Year 1997 & 68.21 & 27.329 & & 68.08 & 27.318 & \\
\hline Year 1998 & 187.30 & 26.975 & $\star *$ & 187.21 & 26.965 & ** \\
\hline Year 1999 & 146.38 & 28.613 & ** & 145.34 & 28.603 & ** \\
\hline Year 2000 & 111.87 & 28.378 & $* *$ & 110.88 & 28.369 & ** \\
\hline Year 2001 & 139.51 & 28.287 & $\star *$ & 138.19 & 28.279 & ** \\
\hline Year 2002 & 236.25 & 28.425 & $* *$ & 234.62 & 28.418 & ** \\
\hline Year 2003 & 273.36 & 28.542 & ** & 272.87 & 28.536 & ** \\
\hline Year 2004 & 394.65 & 30.103 & $\star *$ & 393.51 & 30.096 & ** \\
\hline Year 2005 & 485.56 & 30.033 & ** & 484.58 & 30.028 & ** \\
\hline Year 2006 & 521.26 & 29.844 & $\star *$ & 521.45 & 29.838 & ** \\
\hline Year 2007 & 493.22 & 35.572 & $\star *$ & 494.09 & 35.563 & ** \\
\hline Year 2008 & 401.53 & 35.492 & $\star *$ & 402.97 & 35.483 & ** \\
\hline Year 2009 & 401.10 & 35.969 & ** & 405.35 & 35.960 & ** \\
\hline SIPP 2001 & 27.45 & 18.700 & & 25.35 & 18.691 & \\
\hline SIPP 2004 & 63.05 & 16.550 & * & 60.78 & 16.544 & * \\
\hline SIPP 2008 & 87.94 & 16.741 & $\star *$ & 85.77 & 16.737 & ** \\
\hline N (person-years) & 596635 & & & 596635 & & \\
\hline R-squared & 0.37 & & & 0.3706 & & \\
\hline
\end{tabular}

Source: Authors' tabulations of the 1996, 2001, 2004, 2008 SIPP data matched to the Social Security Administration's Detailed Earnings Record (DER).

Note: Table includes all workers from 1991 to 2009 (to the SIPP interview). ** indicates $p<0.001$, * indicates $p<0.01$ 
Table 11. Logistic Regression of the Likelihood of Wage and Salary Workers Investing DC Contributions in Stocks

\begin{tabular}{|c|c|c|c|}
\hline & $\begin{array}{c}\text { Parameter } \\
\text { Estimate }\end{array}$ & $\begin{array}{r}\text { Standard } \\
\text { Error }\end{array}$ & \\
\hline Intercept & 0.724 & 0.260 & \\
\hline Married & -0.051 & 0.039 & \\
\hline Two earners & -0.010 & 0.037 & \\
\hline Number of dependents & -0.007 & 0.013 & \\
\hline Own a home & 0.023 & 0.029 & \\
\hline Log of total earnings & 0.060 & 0.020 & \\
\hline Become divorced this year & -0.146 & 0.121 & \\
\hline Become widowed this year & 0.053 & 0.304 & \\
\hline Get married this year & 0.087 & 0.088 & \\
\hline $\begin{array}{l}\text { Spouse contributes to a DC plan } \\
\text { Spouse's contribution rate }\end{array}$ & 0.002 & 0.042 & \\
\hline (contribution/earnings) & 0.307 & 0.332 & \\
\hline Employer contributes to plan & 0.203 & 0.031 & ** \\
\hline Have a DB plan & -0.047 & 0.025 & \\
\hline Have a CB plan & -0.056 & 0.051 & \\
\hline Currently work limited & -0.002 & 0.071 & \\
\hline Spouse currently work limited & -0.047 & 0.061 & \\
\hline $\begin{array}{l}\text { Spouse begins to contribute to DC plan this } \\
\text { year }\end{array}$ & -0.087 & 0.083 & \\
\hline Can borrow from pension plan & 0.239 & 0.025 & ** \\
\hline Number of work years since age 20 & 0.007 & 0.003 & \\
\hline Age & -0.016 & 0.009 & \\
\hline Age squared & 0.000 & 0.000 & \\
\hline Year 2003 & 0.095 & 0.039 & \\
\hline Year 2006 & -0.048 & 0.033 & \\
\hline Year 2009 & 0.002 & 0.034 & \\
\hline $\mathbf{N}$ & 42,294 & & \\
\hline-2 Log Likelihood & 44811 & & \\
\hline
\end{tabular}

Source: Authors' tabulations of the 1996, 2001, 2004, 2008 SIPP data matched to the Social Security Administration's Detailed Earnings Record (DER).

Note: Table includes all workers in the pension job who contributed to their 401(k) accounts in the SIPP pension interview year. ** indicates $p<0.001$, * indicates $p<0.01$ 
Table 12. Logistic Regression of the Likelihood of Investing Retirement Account Balances in Stocks

\begin{tabular}{lrr}
\hline & $\begin{array}{r}\text { Parameter } \\
\text { Estimate }\end{array}$ & $\begin{array}{r}\text { Standard } \\
\text { Error }\end{array}$ \\
\hline Intercept & 0.667 & 0.157 \\
Married & -0.006 & 0.032 \\
Two earners & -0.059 & 0.029 \\
Number of dependents & -0.017 & 0.012 \\
Own a home & 0.242 & 0.027 \\
Log of total earnings & 0.029 & 0.004 \\
Become divorced this year & 0.042 & 0.117 \\
Become widowed this year & 0.394 & 0.226 \\
Get married this year & -0.135 & 0.077 \\
Spouse contributes to a DC plan & 0.090 & 0.036 \\
Spouse's contribution rate & & \\
(contribution/earnings) & 0.823 & 0.311 \\
Employer contributes to plan & 0.193 & 0.026 \\
Have a DB plan & -0.048 & 0.024 \\
Have a CB plan & 0.172 & 0.056 \\
Currently work limited & -0.078 & 0.047 \\
Spouse currently work limited & -0.026 & 0.051 \\
Spouse begins to contribute to DC plan this & & \\
year & -0.068 & 0.078 \\
Can borrow from pension plan & 0.163 & 0.027 \\
Number of work years since age 20 & 0.014 & 0.002 \\
Age & -0.003 & 0.007 \\
Age squared & -0.0002 & 0.0001 \\
Year 2003 & 0.341 & 0.035 \\
Year 2006 & 0.549 & 0.029 \\
Year 2009 & 0.107 & 0.028 \\
N & & \\
-2 Log Likelihood & 58,993 & \\
\hline & 60128 & \\
\hline & & \\
\hline
\end{tabular}

Source: Authors' tabulations of the 1996, 2001, 2004, 2008 SIPP data matched to the Social Security Administration's Detailed Earnings Record (DER).

Note: Table includes all workers with retirement account assets in the SIPP asset interview year. ${ }^{*}$ indicates $p<0.001$, * indicates $p<0.01$ 
Table 13. The Short-Run Impact of the Recession on Retirement Account Balances for Participants Ages 20 to 69 (in 2011 dollars)

Accumulated Contributions 2007 through 2009

Baseline

$\$ 7,658$

Alternative Scenario 1

$\$ 7,868$

Alternative Scenario 2

$\$ 7,947$

Difference in Accumulated Contributions Between Baseline and Alternative Scenario (\$)

Alternative Scenario 1

$\$ 210$

Alternative Scenario 2

$\$ 289$

Difference in Accumulated Contributions Between Baseline and Alternative Scenario (\%)

Alternative Scenario 1

$2.7 \%$

Alternative Scenario 2

$3.8 \%$

Source: Authors' tabulations of the 1996, 2001, 2004, 2008 SIPP data matched to the Social Security Administration's Detailed Earnings Record (DER).

Note: Contributions are based on positive deferred contributions on the DER from 1990 to 2010.

Alternative scenario 1 assumes that contributions in 2008 and 2009 remain at the 2007 level.

Alternative scenario 2 assumes that contributions increase 1 percent each year after 2007. 
Table 14. The Long-Run Impact of the Recession on Retirement Account Balances at Age 62 (in 2011 dollars)

\begin{tabular}{|c|c|c|c|c|c|c|c|}
\hline \multirow[b]{2}{*}{ Year } & \multirow[b]{2}{*}{ Age } & \multicolumn{2}{|c|}{ Average 30-year-old } & \multicolumn{2}{|c|}{ Baseline } & \multicolumn{2}{|c|}{ Alternative Scenario } \\
\hline & & Orig & \%Change & Contrib. & Balance & Contrib. & Balance \\
\hline 2007 & 30 & 2,304 & & 2,304 & 2,304 & 2,304 & 2,304 \\
\hline 2008 & 31 & 2,327 & $1.0 \%$ & 2,226 & 4,599 & 2,327 & 4,700 \\
\hline 2009 & 32 & 2,350 & $1.0 \%$ & 2,165 & 6,902 & 2,350 & 7,191 \\
\hline 2010 & 33 & 2,374 & $1.0 \%$ & 2,166 & 9,276 & 2,374 & 9,781 \\
\hline 2011 & 34 & 2,398 & $1.0 \%$ & 2,188 & 11,742 & 2,398 & 12,472 \\
\hline 2012 & 35 & 2,422 & $1.0 \%$ & 2,210 & 14,304 & 2,422 & 15,268 \\
\hline 2013 & 36 & 2,446 & $1.0 \%$ & 2,232 & 16,965 & 2,446 & 18,171 \\
\hline 2014 & 37 & 2,470 & $1.0 \%$ & 2,254 & 19,728 & 2,470 & 21,187 \\
\hline 2015 & 38 & 2,495 & $1.0 \%$ & 2,277 & 22,596 & 2,495 & 24,317 \\
\hline 2016 & 39 & 2,520 & $1.0 \%$ & 2,299 & 25,574 & 2,520 & 27,567 \\
\hline 2017 & 40 & 2,545 & $1.0 \%$ & 2,322 & 28,663 & 2,545 & 30,939 \\
\hline 2018 & 41 & 2,570 & $1.0 \%$ & 2,346 & 31,869 & 2,570 & 34,437 \\
\hline 2019 & 42 & 2,596 & $1.0 \%$ & 2,369 & 35,194 & 2,596 & 38,067 \\
\hline 2020 & 43 & 2,622 & $1.0 \%$ & 2,393 & 38,643 & 2,622 & 41,831 \\
\hline 2021 & 44 & 2,648 & $1.0 \%$ & 2,417 & 42,219 & 2,648 & 45,734 \\
\hline 2022 & 45 & 2,675 & $1.0 \%$ & 2,441 & 45,926 & 2,675 & 49,781 \\
\hline 2023 & 46 & 2,702 & $1.0 \%$ & 2,465 & 49,769 & 2,702 & 53,976 \\
\hline 2024 & 47 & 2,729 & $1.0 \%$ & 2,490 & 53,752 & 2,729 & 58,324 \\
\hline 2025 & 48 & 2,756 & $1.0 \%$ & 2,515 & 57,880 & 2,756 & 62,830 \\
\hline 2026 & 49 & 2,783 & $1.0 \%$ & 2,540 & 62,156 & 2,783 & 67,498 \\
\hline 2027 & 50 & 2,811 & $1.0 \%$ & 2,565 & 66,586 & 2,811 & 72,334 \\
\hline 2028 & 51 & 2,839 & $1.0 \%$ & 2,591 & 71,175 & 2,839 & 77,344 \\
\hline 2029 & 52 & 2,868 & $1.0 \%$ & 2,617 & 75,927 & 2,868 & 82,532 \\
\hline 2030 & 53 & 2,897 & $1.0 \%$ & 2,643 & 80,848 & 2,897 & 87,904 \\
\hline 2031 & 54 & 2,925 & $1.0 \%$ & 2,670 & 85,944 & 2,925 & 93,467 \\
\hline 2032 & 55 & 2,955 & $1.0 \%$ & 2,696 & 91,218 & 2,955 & 99,226 \\
\hline 2033 & 56 & 2,984 & $1.0 \%$ & 2,723 & 96,678 & 2,984 & 105,187 \\
\hline 2034 & 57 & 3,014 & $1.0 \%$ & 2,750 & 102,329 & 3,014 & 111,357 \\
\hline 2035 & 58 & 3,044 & $1.0 \%$ & 2,778 & 108,177 & 3,044 & 117,741 \\
\hline 2036 & 59 & 3,075 & $1.0 \%$ & 2,806 & 114,228 & 3,075 & 124,348 \\
\hline 2037 & 60 & 3,105 & $1.0 \%$ & 2,834 & 120,488 & 3,105 & 131,184 \\
\hline 2038 & 61 & 3,136 & $1.0 \%$ & 2,862 & 126,965 & 3,136 & 138,256 \\
\hline 2039 & 62 & 3,168 & $1.0 \%$ & 2,891 & 133,665 & 3,168 & 145,572 \\
\hline \multicolumn{8}{|c|}{$\begin{array}{l}\text { Change in Accumulated } \\
\text { Balance }\end{array}$} \\
\hline Level & & & & & & & 11,907 \\
\hline Percent & & & & & & & $8.9 \%$ \\
\hline
\end{tabular}

Source: Authors' tabulations of the 1996, 2001, 2004, 2008 SIPP data matched to the Social Security Administration's Detailed Earnings Record (DER).

Note: Contributions are based on positive deferred contributions on the DER from 1990 to the SIPP interview year. The baseline scenario assumes that contributions increase 1 percent each year after 2010. The alternative scenario assumes that contributions increase 1 percent each year after 2007. Both scenarios assume a 3 percent rate of return on account balances. 


\section{RECENT WORKING PAPERS FROM THE CENTER FOR RETIREMENT RESEARCH AT BOSTON COLLEGE}

Immigrant Networks and the Take-Up of Disability Programs: Evidence from U.S. Census Data

Delia Furtado and Nikolaos Theodoropoulos, October 2012

Will Delayed Retirement by the Baby Boomers Lead to Higher Unemployment Among Younger Workers?

Alicia H. Munnell and April Yanyuan Wu, October 2012

Growth in Health Consumption and Its Implications for Financing OASDI: An International Perspective

Barry P. Bosworth and Gary Burtless, September 2012

Using Participant Data to Improve 401(k) Asset Allocation

Zhenyu Li and Anthony Webb, September 2012

Job Demand and Early Retirement

Sepideh Modrek and Mark R. Cullen, August 2012

Changes in Labor Force Participation of Older Americans and Their Pension Structures: A Policy Perspective

Frank W. Heiland and Zhe Li, July 2012

How Would GASB Proposals Affect State and Local Pension Reporting?

Alicia H. Munnell, Jean-Pierre Aubry, Joshua Hurwitz and Laura Quinby, June 2012

Borrow Less Tomorrow: Behavioral Approaches to Debt Reduction

Dean Karlan and Jonathan Zinman, May 2012

Spousal Labor Market Effects from Government Health Insurance: Evidence from A Veterans Affairs Expansion

Melissa A. Boyle and Joanna N. Lahey, April 2012

Measuring Social Security Proposals by More than Solvency: Impacts on Poverty, Progressivity, Horizontal Equity, and Work Incentives

Melissa M. Favreault and C. Eugene Steuerle, April 2012

How Important Is Asset Allocation to Financial Security in Retirement?

Alicia H. Munnell, Natalia Sergeyevna Orlova, and Anthony Webb, April 2012

Great Recession-Induced Early Claimers: Who Are They? How Much Do They Lose? Matthew S. Rutledge and Norma B. Coe, April 2012

All working papers are available on the Center for Retirement Research website (http://crr.bc.edu) and can be requested by e-mail (crr@bc.edu) or phone (617-552-1762). 